\title{
Integrative taxonomy of the rock-dwelling gecko Cnemaspis siamensis complex (Squamata, Gekkonidae) reveals a new species from Nakhon Si Thammarat Province, southern Thailand
}

\author{
Natee Ampai',2, Perry L. Wood Jr ${ }^{3}$, Bryan L. Stuart ${ }^{4}$, Anchalee Aowphol' \\ I Department of Zoology, Faculty of Science, Kasetsart University, Bangkok, 10900 Thailand 2 Department of \\ Biology, Faculty of Science, Srinakharinwirot University, Bangkok, 10110 Thailand 3 Department of Biologi- \\ cal Sciences and Museum of Natural History, Auburn University, Auburn, AL, USA 4 Section of Research and \\ Collections, North Carolina Museum of Natural Sciences, Raleigh, NC, USA \\ Corresponding author: Anchalee Aowphol (fsciacl@ku.ac.th) \\ Academic editor: A. Bauer | Received 29 January 2020 | Accepted 21 March 2020 | Published 12 May 2020 \\ http://zoobank.org/FE3B850B-5807-47F6-BB9C-43D10AA47BAC \\ Citation: Ampai N, Wood Jr PL, Stuart BL, Aowphol A (2020) Integrative taxonomy of the rock-dwelling gecko \\ Cnemaspis siamensis complex (Squamata, Gekkonidae) reveals a new species from Nakhon Si Thammarat Province, \\ southern Thailand. ZooKeys 932: 129-159. https://doi.org/10.3897/zookeys.932.50602
}

\begin{abstract}
The rock-dwelling gecko genus Cnemaspis is one of the most species-diverse genera of gekkonid in Thailand. Earlier studies relied on morphological data to identify species, but cryptic morphology often obscured species diversity in Cnemaspis. In this study, an integrative taxonomic approach based on morphological characters and sequences of the mitochondrial NADH dehydrogenase subunit 2 (ND2) gene were used to clarify current taxonomy of the Cnemaspis siamensis complex and delimit a new species from Lan Saka District, Nakhon Si Thammarat Province, southern Thailand. Cnemaspis lineatubercularis sp. nov. is distinguished from other congeneric species by the combination of morphological characters: (1) maximum snout-vent length (SVL) of $40.6 \mathrm{~mm}$ (mean $38.8 \pm \mathrm{SD} 1.4, N=12$ ) in adult males and maximum SVL of $41.8 \mathrm{~mm}$ (mean $39.5 \pm$ SD 1.9, $N=7$ ) in adult females; (2) 8-9 supralabial and infralabial scales; (3) gular, pectoral, abdominal, and subcaudal scales keeled; (4) rostral, interorbitals, supercilium, palmar scales, and ventral scales of brachia smooth; (5) 5-6 small, subconical spine-like tubercles present on flanks; (6) 19-21 paravertebral tubercles linearly arranged; (7) 27-29 subdigital lamellae under the fourth toe; (8) 4-7 pore-bearing precloacal scales, pores rounded arranged in chevron shape and separated only in males; (9) one postcloacal tubercles each side in males; (10) ventrolateral caudal tubercles present anteriorly; (11) caudal tubercles restricted to a single paravertebral row on each side; (12) single median
\end{abstract}

Copyright Natee Ampai et al. This is an open access article distributed under the terms of the Creative Commons Attribution License (CC BY 4.0), which permits unrestricted use, distribution, and reproduction in any medium, provided the original author and source are credited. 
row of subcaudal scales keeled and lacking enlarged median row; and (13) gular region, abdomen, limbs and subcaudal region yellowish only in males. Genetically, the uncorrected pairwise divergences between the new species and their congeners in the C. siamensis group were between 15.53-28.09\%. The new species is currently known only from granitic rocky streams at Wang Mai Pak Waterfall in the Nakhon Si Thammarat mountain range. Its discovery suggests that additional unrecognized species of Cnemaspis may still occur in unexplored areas of southern Thailand.

\section{Keywords}

Cnemaspis, morphology, phylogeny, species diversity, taxonomy, Thailand

\section{Introduction}

The rock-dwelling gecko genus Cnemaspis Strauch, 1887 is one of the most speciose genera in the family Gekkonidae. The genus is geographically widespread from tropical Africa eastward through South Asia, southward to Southeast Asia (Bauer et al. 2007; Grismer et al. 2014). However, recent molecular phylogenetic analyses of Cnemaspis suggest the genus may be polyphyletic, with three separate, unrelated clades consisting of African, South Asian, and Southeast Asian clades (Gamble et al. 2012; Pyron et al. 2013).

Southeast Asian Cnemaspis is a monophyletic group (Gamble et al. 2012; Pyron et al. 2013) that contains 59 species distributed from Laos, southern Vietnam, Cambodia, Thailand, southward through the Thai-Malay Peninsula to Borneo, Java, and Sumatra (Bauer and Das 1998; Das 2005; Bauer et al. 2007; Grismer and Ngo 2007; Grismer et al. 2009, 2014; Grismer and Chan 2010; Kurita et al. 2017; Riyanto et al. 2017; Uetz et al. 2019). In Thailand, there are currently 17 recognized species of Cnemaspis (Grismer et al. 2010, 2014; Wood et al. 2017; Ampai et al. 2019; Uetz et al. 2019), ranging from Kanchanaburi Province, western Thailand (Grismer et al. 2010) to Chanthaburi Province, eastern Thailand (Bauer and Das 1998), southward through southern Thailand and its offshore islands (Grismer et al 2014; Wood et al. 2017; Ampai et al. 2019). Based on the combination of morphological characters and molecular data, Grismer et al. (2014) indicated that Cnemaspis species from Thailand belong to four species groups, consisting of the affinis group, the chanthaburiensis group, the kumpoli group (= Pattani clade of Grismer et al. 2014) and the siamensis group.

The siamensis group is the most species-diverse of the Cnemaspis group in Thailand, and the number of described species in the group has increased rapidly during the past decade (e.g., Grismer et al. 2010, 2014; Wood et al. 2017; Ampai et al. 2019). Currently, there are eleven recognized species in the siamensis group: C. adangrawi Ampai et al., 2019, C. chanardi Grismer et al., 2010, C. huaseesom Grismer et al., 2010, C. kamolnorranathi Grismer et al., 2010, C. omari Grismer et al., 2014, C. phangngaensis Wood et al., 2017, C. punctatonuchalis Grismer et al., 2010, C. roticanai Grismer \& Onn, 2010, C. siamensis Smith, 1925, C. thachanaensis Wood et al., 2017 and $C$. vandeventeri Grismer et al., 2010. The siamensis group is diagnosed by having 
a moderate body size of 37.8-49.6 mm snout-vent length (SVL); 7-11 supralabials; 6-11 infralabials; $0-8$ pore-bearing precloacal scales; $15-29$ paravertebral tubercles; 1-3 postcloacal tubercles in males; $21-31$ lamellae beneath the fourth toe; and a lightcolored prescapular crescent (Grismer et al. 2010, 2014; Wood et al. 2017; Ampai et al. 2019). Despite the high number of species already described in the siamensis group in Thailand, additional taxonomic diversity likely exists (Grismer et al. 2010, 2014; Wood et al. 2017).

More than half of Southeast Asian Cnemaspis species have been described primarily or solely on the basis of morphological characteristics (Smith 1925; Taylor 1963; Bauer and Das 1998; Das and Leong 2004; Das 2005; Bauer et al. 2007; Grismer et al. 2010). However, morphological data alone has been insufficient for resolving some taxonomic issues that are confounded by morphological crypsis. During the past decade, an integrative taxonomic approach that uses multiple sources of data (e.g., morphology, DNA sequencing, ecology, biogeography, behavior) to delimit species and describe taxa (Dayrat 2005) has been shown to be very effective in revealing cryptic species diversity and microhabitat specialization in Southeast Asian Cnemaspis (e.g., Grismer et al. 2013, 2014; Wood et al. 2013, 2017; Kurita et al. 2017; Ampai et al. 2019).

During fieldwork in October 2016 and January 2019, we collected specimens of the C. siamensis group at Wang Mai Pak Waterfall, Lan Saka District, Nakhon Si Thammarat Province, southern Thailand that could not be referred to any named species. We examine qualitative and quantitative (univariate and multivariate analyses) variation in morphology and mitochondrial DNA sequence data and show that the Lan Saka specimens differ from all other species of Cnemaspis. On the basis of this integrative approach, we described the Lan Saka population as a new species.

\section{Materials and methods}

\section{Sampling}

Specimens of Cnemaspis were collected by hand during the day (1000-1800 h) and at night (1900-2200 h) between October 2016 and January 2019 from Wang Mai Pak Waterfall, Lan Saka District, Nakhon Si Thammarat Province, Thailand. Liver samples for genetic analysis were taken from euthanized specimens and preserved in $95 \%$ ethanol. Specimens were then fixed in 10\% formalin and later transferred to $70 \%$ ethanol for permanent storage. Specimens and tissue samples were deposited in the herpetological collection at the Zoological Museum of Kasetsart University, Bangkok, Thailand (ZMKU) and the Thailand Natural History Museum, Pathum Thani, Thailand (THNHM). Comparative material was also examined in the holdings of these institutions (Appendix 1), and comparative data were obtained from the original descriptions of other Cnemaspis species in Thailand (Grismer et al. 2010; Wood et al. 2017; Ampai et al. 2019). 


\section{Morphological measurements}

The following morphometric measurements were taken by the first author on the left side of preserved specimens to the nearest $0.1 \mathrm{~mm}$ using digital calipers under a Nikon SMZ 745 dissecting microscope. Morphological measurements were taken only from adult individuals as determined by the presence of secondary sexual characteristics including the presence of hemipenes or pore-bearing precloacal scales in males, and the presence of calcium glands or eggs in females. Sixteen morphological measurements were taken following Grismer et al. (2014) and Wood et al. (2017): snout-vent length (SVL), taken from tip of snout to the anterior margin of vent; tail width (TW) at the base of the tail immediately posterior to the postcloacal swelling; tail length (TL), as distance from the vent to the tip of the tail, whether original or regenerated; forearm length $(\mathbf{F L})$, taken on the dorsal surface from the posterior margin of the elbow while flexed $90^{\circ}$ to the inflection of the flexed wrist; tibia length (TBL), taken on the ventral surface from the posterior surface of the knee while flexed $90^{\circ}$ to the base of the heel; head length $(\mathbf{H L})$, as distance from the posterior margin of the retroarticular process of the lower jaw to the tip of the snout; head width (HW) at the angle of the jaws; head depth (HD), as the maximum height of head from the occiput to the throat; axilla-groin length (AG), taken from the posterior margin of the forelimb at its insertion point on the body to the anterior margin of the hind limb at its insertion point on the body; eye diameter (ED), as the maximum horizontal diameter of the eyeball; eye-ear distance (EE), measured from the anterior margin of the ear opening to the posterior edge of the eyeball; ear length (EL), taken from the greatest vertical distance of the ear opening; eye-nostril distance (EN), measured from the anterior most margin of the eyeball to the posterior margin of the external nares; eye-snout distance (ES), measured from the anterior margin of the eyeball to the tip of snout; inner orbital distance (IO), as the width of the frontal bone at the level of the anterior edges of the orbit; and internarial distance (IN), measured between the medial margins of the nares across the rostrum.

Meristic characters of scales and qualitative observations of other structures were made through a Nikon SMZ 745 dissecting microscope. The external observations of meristic characters were taken following Grismer et al. (2014) and Wood et al. (2017): number of supralabial (SUP) and infralabial (INF) scales, counted from below the middle of the orbit to the rostral and mental scales, respectively; texture of scales on the anterior margin of the forearm; number of paravertebral tubercles (PVT) between limb insertions, counted in a straight line immediately left of the vertebral column; general size (i.e., strong, moderate, weak) and arrangement (i.e., random or linear) of dorsal body tubercles; number of subdigital lamellae beneath the fourth toe $\left(=4^{\text {th }}\right.$ toe lamellae), counted from the base of the first phalanx to the claw; presence or absence of a row of enlarged, widely spaced, tubercles along the ventrolateral edge of the body flank between limb insertions; number, orientation and shape of pore-bearing precloacal scales; relative size of subcaudal and subtibial scales; and number of postcloacal tubercles on each side of tail base. 


\section{Morphological analysis}

Statistical analyses were used to compare differences in size and shape in the siamensis group, including the Lan Saka samples $(N=19)$ and four congeners in the siamensis group: $C$. adangrawi $(N=8), C$. chanardi $(N=7), C$. omari $(N=5)$ and $C$. siamensis $(N=8)$. Other species in the siamensis group $(C$. huaseesom, $C$. kamolnorranathi, $C$. phangngaensis, C. punctatonuchalis, C. roticanai, C. thachanaensis, and C. vandeventeri) were not included in the morphometric analyses due to lack of specimens. Five putative operational taxonomic units (OTUs) were assigned on the basis of observed variation in morphometric analysis. Fifteen morphometric variables (SVL, TW, FL, TBL, HL, HW, HD, AG, EE, ED, EL, EN, ES, IO, and IN) were corrected for differences in ontogenetic composition by the following allometric equation: $\mathrm{X}_{\mathrm{adj}}=\mathrm{X}$ $-\beta\left(S V L-S V L_{\text {mean }}\right)$, where $X_{\text {adj }}$ is the adjusted value of the morphometric variable; $X$ is the original value; $\beta$ is the within-clade coefficient of the linear regression of each original character value $(\mathrm{X})$ against $\mathrm{SVL} ; \mathrm{SVL}=$ snout-vent length; $\mathrm{SVL}_{\text {mean }}=$ overall average SVL length of OTUs (Thorpe 1975, 1983; Turan 1999; Lleonart et al. 2000). Tail length (TL) was not included due to the differences in length between original and regenerated tails. Univariate analyses were implemented in the statistic software PAST 3.24 (Hammer et al. 2001) using an analysis of variance (ANOVA) to compare morphological differentiation in traits among the Lan Saka samples and the five congeners in the siamensis group. ANOVAs having $p$-value less than 0.05 were subjected to a Tukey's honestly significant difference (HSD) test to identify all pairwise comparisons among sample means for significant differences $(p<0.05)$.

Multivariate analyses were performed using the base statistical software in RStudio v. 1.2.1335 (RStudio Team 2018). A principal component analysis (PCA) using the built-in R functions: prcomp (R Core Team 2018) and ggplot2 (Wickham 2016) were performed to find the best low-dimensional space of morphological variation in data. Principal components (PCs) with eigenvalues greater than 1.0 were retained in accordance to the criterion of Kaiser (1960). A discriminant analysis of principal components (DAPC) was performed using the adegenet function (Jombart 2008) to characterize clustering and distance in morphospace. The DAPC was used for all congeners to find the linear combinations of morphological variables that have the greatest between-group variance and the smallest within-group variance. The DAPC relies on data transformation using PCA as a prior step to ensure that variables included in the discriminant analysis (DA) are uncorrected and number fewer than the sample size (Jombart et al. 2010).

\section{Genetic analysis}

Genomic DNA was extracted from liver tissue of five individuals of Cnemaspis (Table 1) using the Qiagen DNAeasy tissue kit (Valencia, CA, USA). A 1,251 bp fragment of mitochondrial (mt) DNA consisting of the NADH dehydrogenase subunit 2 (ND2) gene and the flanking tRNAs Trp, Ala, Asn, and Cys was amplified using 
Table I. Specimens used in this study, including locality, collection numbers and Genbank accession numbers. Voucher abbreviations are as follows: Monte L. Bean Life Science Museum at Brigham Young University (BYU), California Academy of Sciences (CAS), the Field Museum of Natural History, Chicago, Illinois, USA (FMNH), La Sierra University Herpetological Collection (LSUHC), Universiti Sains Malaysia Herpetological Collection at the Universiti Sains Malaysia, Penang, Malaysia (USMHC), and Zoological Museum of Kasetsart University (ZMKU).

\begin{tabular}{|c|c|c|c|c|}
\hline Species & Locality & Collection number & \begin{tabular}{|c|} 
GenBank \\
accession number
\end{tabular} & Reference \\
\hline Cyrtodactylus bokorensis & Cambodia, Kampot & FMNH 263228 & KT13107 & Grismer et al. 2015a \\
\hline Hemidactylus garnotii & $\begin{array}{c}\text { Myanmar, Mon State, } \\
\text { Kyait Hti Yo Wildlife Sanctuary }\end{array}$ & CAS 222276 & EU68364 & Bauer et al. 2008 \\
\hline \multirow[t]{5}{*}{ Cnemaspis adangrawi } & \multirow{5}{*}{$\begin{array}{l}\text { Thailand, Satun Province, } \\
\text { Mueang Satun District, } \\
\text { Adang Island } \\
\text { Thailand, Satun Province, } \\
\text { Mueang Satun District, Rawi Island }\end{array}$} & ZMKU R 00767 & MK862112 & Ampai et al. 2019 \\
\hline & & THNHM 28207 & MK862113 & Ampai et al. 2019 \\
\hline & & ZMKU R 00770 & MK862114 & Ampai et al. 2019 \\
\hline & & ZMKU R 00775 & MK862115 & Ampai et al. 2019 \\
\hline & & ZMKU R 00776 & MK862116 & Ampai et al. 2019 \\
\hline Cnemaspis affnis & Malaysia, Penang, Pulau Pinang & LSUHC 6787 & KM024682 & Grismer et al. 2014 \\
\hline \multirow[t]{2}{*}{ Cnemaspis argus } & \multirow{2}{*}{$\begin{array}{l}\text { Malaysia, Terengganu, } \\
\text { Gunung Lawit }\end{array}$} & LSUHC 8304 & KM024687 & Grismer et al. 2014 \\
\hline & & LSUHC 10834 & KM024688 & Grismer et al. 2014 \\
\hline \multirow{2}{*}{ Cnemaspis aurantiacopes } & \multirow{2}{*}{$\begin{array}{c}\text { Vietnam, Kien Giang Province, } \\
\text { Hon Dat Hill }\end{array}$} & LSUHC 8610 & KM024692 & Grismer et al. 2014 \\
\hline & & LSUHC 8611 & KM024693 & Grismer et al. 2014 \\
\hline \multirow[t]{3}{*}{ Cnemaspis biocellata } & \multirow[t]{3}{*}{ Malaysia, Perlis, Kuala Perlis } & LSUHC 8817 & KM024707 & Grismer et al. 2014 \\
\hline & & LSUHC 8817 & KM024708 & Grismer et al. 2014 \\
\hline & & LSUHC 8789 & KM024709 & Grismer et al. 2014 \\
\hline \multirow[t]{2}{*}{ Cnemaspis boulengerii } & \multirow{2}{*}{$\begin{array}{l}\text { Vietnam, Ca Mau Province, } \\
\text { Con Dao Archipelago }\end{array}$} & LSUHC 9278 & KM024710 & Grismer et al. 2014 \\
\hline & & LSUHC 9279 & KM024711 & Grismer et al. 2014 \\
\hline Cnemaspis caudanivea & $\begin{array}{c}\text { Vietnam, Kien Giang Province, } \\
\text { Hon Tre Island }\end{array}$ & LSUHC 8582 & KM024714 & Grismer et al. 2014 \\
\hline Cnemaspis chanardi & $\begin{array}{l}\text { Thailand, Nakhon Si Thammarat } \\
\text { Province, Thum Thong Panra }\end{array}$ & LSUHC 9567 & KM024715 & Grismer et al. 2014 \\
\hline Cnemaspis chanthaburiensis & $\begin{array}{c}\text { Cambodia, Pursat Province, Phnom } \\
\text { Dalai }\end{array}$ & LSUHC 9338 & KM024716 & Grismer et al. 2014 \\
\hline Cnemaspis grismeri & Malaysia, Perak, Lenggong & LSUHC 9969 & KM024722 & Grismer et al. 2014 \\
\hline Cnemaspis hangus & Malaysia, Pahang, Bukit Hangus & LSUHC 9358b & KM024728 & Grismer et al. 2014 \\
\hline Cnemaspis harimau & Malaysia, Kedah, Gunung Jeri & LSUHC 9665 & KM024730 & Grismer et al. 2014 \\
\hline \multirow[t]{3}{*}{ Cnemaspis huaseesom } & \multirow{3}{*}{$\begin{array}{c}\text { Thailand, Kanchanaburi Province, } \\
\text { Sai Yok National Park }\end{array}$} & LSUHC 9455 & KM024733 & Grismer et al. 2014 \\
\hline & & LSUHC 9457 & KM024734 & Grismer et al. 2014 \\
\hline & & LSUHC 9458 & KM024735 & Grismer et al. 2014 \\
\hline \multirow[t]{2}{*}{ Cnemaspis karsticola } & \multirow[t]{2}{*}{ Malaysia, Kelantan, Gunung Reng } & LSUHC 9054 & KM024736 & Grismer et al. 2014 \\
\hline & & LSUHC 9055 & KM024737 & Grismer et al. 2014 \\
\hline \multirow[t]{2}{*}{ Cnemaspis kumpoli } & \multirow[t]{2}{*}{ Malaysia, Perlis, Perlis State Park } & LSUHC 8847 & KM024745 & Grismer et al. 2014 \\
\hline & & LSUHC 8848 & KM024746 & Grismer et al. 2014 \\
\hline \multirow{5}{*}{$\begin{array}{l}\text { Cnemaspis lineatubercularis } \\
\text { sp. nov. }\end{array}$} & \multirow{5}{*}{$\begin{array}{c}\text { Thailand, Nakhon Si Thammarat } \\
\text { Province, Lan Saka District, Wang } \\
\text { Mai Pak Waterfall }\end{array}$} & ZMKU R 00825 & MT112890 & This study \\
\hline & & ZMKU R 00828 & MT112891 & This study \\
\hline & & ZMKU R 00829 & MT112892 & This study \\
\hline & & ZMKU R 00830 & MT112893 & This study \\
\hline & & ZMKU R 00832 & MT112894 & This study \\
\hline \multirow[t]{2}{*}{ Cnemaspis lineogularis } & \multirow{2}{*}{$\begin{array}{l}\text { Thailand, Prachuap Khiri Khan } \\
\text { Province, } \\
\text { Kui Buri District, Wat Khao Daeng }\end{array}$} & BYU 62535 & KY091231 & Wood et al. 2017 \\
\hline & & ZMKU R 00728 & KY091233 & Wood et al. 2017 \\
\hline Cnemaspis mahsuriae & $\begin{array}{c}\text { Malaysia, Kedah, Pulau Langkawi, } \\
\text { Gunung Raya }\end{array}$ & LSUHC 11829 & KT250634 & Grismer et al. $2015 b$ \\
\hline Cnemaspis meguirei & Malaysia, Perak, Bukit Larut & LSUHC 8853 & KM024751 & Grismer et al. 2014 \\
\hline \multirow[t]{2}{*}{ Cnemaspis monachorum } & \multirow{2}{*}{$\begin{array}{l}\text { Malaysia, Kedah, Langkawi } \\
\text { Archipelago, Pulau Langkawi }\end{array}$} & LSUHC 9114 & KM024754 & Grismer et al. 2014 \\
\hline & & LSUHC 10807 & KM024755 & Grismer et al. 2014 \\
\hline \multirow[t]{2}{*}{ Cnemaspis narathiwatensis } & \multirow{2}{*}{$\begin{array}{l}\text { Malaysia, Perak, Belum-Temengor, } \\
\text { Sungai Enam }\end{array}$} & USMHC 1347 & KM024762 & Grismer et al. 2014 \\
\hline & & USMHC 1348 & KM024763 & Grismer et al. 2014 \\
\hline
\end{tabular}




\begin{tabular}{|c|c|c|c|c|}
\hline Species & Locality & Collection number & \begin{tabular}{c|} 
GenBank \\
accession number
\end{tabular} & Reference \\
\hline \multirow[t]{2}{*}{ Cnemaspis neangthyi } & \multirow{2}{*}{$\begin{array}{c}\text { Cambodia, Pursat Province, } \\
\text { O'Lakmeas }\end{array}$} & LSUHC 8515 & KM024767 & Grismer et al. 2014 \\
\hline & & LSUHC 8516 & KM024768 & Grismer et al. 2014 \\
\hline \multirow[t]{2}{*}{ Cnemaspis niyomwanae } & \multirow{2}{*}{$\begin{array}{c}\text { Thailand, Trang Province, } \\
\text { Thum Khao Ting }\end{array}$} & LSUHC 9568 & KM024773 & Grismer et al. 2014 \\
\hline & & LSUHC 9571 & KM024774 & Grismer et al. 2014 \\
\hline \multirow[t]{3}{*}{ Cnemaspis nuicamensis } & \multirow{3}{*}{$\begin{array}{c}\text { Vietnam, An Giang Province, Nui } \\
\text { Cam Hill }\end{array}$} & LSUHC 8646 & KM024775 & Grismer et al. 2014 \\
\hline & & LSUHC 8647 & KM024776 & Grismer et al. 2014 \\
\hline & & LSUHC 8648 & KM024777 & Grismer et al. 2014 \\
\hline \multirow[t]{2}{*}{ Cnemaspis omari } & \multirow{2}{*}{$\begin{array}{c}\text { Thailand, Satun Province, } \\
\text { Phuphaphet Cave } \\
\text { Malaysia, Perlis, Perlis State Park }\end{array}$} & LSUHC 9565 & KM024780 & Grismer et al. 2014 \\
\hline & & LSUHC 9978 & KM024779 & Grismer et al. 2014 \\
\hline Cnemaspis perhentianensis & $\begin{array}{l}\text { Malaysia, Terengganu, Pulau } \\
\text { Perhentian Besar }\end{array}$ & LSUHC 8699 & KM024820 & Grismer et al. 2014 \\
\hline \multirow[t]{2}{*}{ Cnemaspis phangngaensis } & \multirow{2}{*}{$\begin{array}{l}\text { Thailand, Phangnga Province, } \\
\text { Mueang Phangnga District, Khao } \\
\text { Chang, Phung Chang Cave }\end{array}$} & BYU 62537 & KY091234 & Wood et al. 2017 \\
\hline & & BYU 62538 & KY091235 & Wood et al. 2017 \\
\hline \multirow[t]{2}{*}{ Cnemaspis punctatonuchalis } & \multirow{2}{*}{$\begin{array}{l}\text { Thailand, Prachaup Khiri Khan } \\
\text { Province, Thap Sakae }\end{array}$} & BYU 62539 & KY091236 & Wood et al. 2017 \\
\hline & & BYU 62540 & KY091237 & Wood et al. 2017 \\
\hline \multirow[t]{3}{*}{ Cnemaspis roticanai } & \multirow{3}{*}{$\begin{array}{l}\text { Malaysia, Kedah, Pulau Langkawi, } \\
\text { Gunung Raya }\end{array}$} & LSUHC 9430 & KM024829 & Grismer et al. 2014 \\
\hline & & LSUHC 9431 & KM024830 & Grismer et al. 2014 \\
\hline & & LSUHC 9439 & KM024831 & Grismer et al. 2014 \\
\hline \multirow[t]{2}{*}{ Cnemaspis siamensis } & \multirow{2}{*}{$\begin{array}{c}\text { Thailand, Chumpon Province, } \\
\text { Pathio District }\end{array}$} & LSUHC 9474 & KM024838 & Grismer et al. 2014 \\
\hline & & LSUHC 9485 & KM024839 & Grismer et al. 2014 \\
\hline \multirow[t]{3}{*}{ Cnemaspis tarutaoensis } & \multirow{3}{*}{$\begin{array}{c}\text { Thailand, Satun Province, } \\
\text { Mueang Satun District, } \\
\text { Tarutao Island }\end{array}$} & ZMKU R 00761 & MK862117 & Ampai et al. 2019 \\
\hline & & ZMKUR 00763 & MK862118 & Ampai et al. 2019 \\
\hline & & ZMKU R 00764 & MK862119 & Ampai et al. 2019 \\
\hline \multirow[t]{3}{*}{ Cnemaspis thachanaensis } & \multirow{3}{*}{$\begin{array}{c}\text { Thailand, Surat Thani Province, } \\
\text { Tha Chana District, } \\
\text { Tham Khao Sonk Hill }\end{array}$} & BYU 62542 & KY091239 & Wood et al. 2017 \\
\hline & & BYU 62543 & KY091243 & Wood et al. 2017 \\
\hline & & BYU 62544 & KY091244 & Wood et al. 2017 \\
\hline \multirow[t]{2}{*}{ Cnemaspis tucdupensis } & \multirow{2}{*}{$\begin{array}{c}\text { Vietnam, An Giang Province, } \\
\text { Tuc Dup Hill }\end{array}$} & LSUHC 8631 & KM024852 & Grismer et al. 2014 \\
\hline & & LSUHC 8632 & KM024853 & Grismer et al. 2014 \\
\hline Cnemaspis vandeventeri & $\begin{array}{l}\text { Thailand, Ranong Province, Suk } \\
\text { Saran District, Naka }\end{array}$ & BYU 62541 & KY091238 & Wood et al. 2017 \\
\hline
\end{tabular}

polymerase chain reaction (PCR) under the following conditions: initial denaturation at $95^{\circ} \mathrm{C}$ for $2 \mathrm{~min}$, followed by a second denaturation at $95^{\circ} \mathrm{C}$ for $35 \mathrm{sec}$, annealing at $52{ }^{\circ} \mathrm{C}$ for $35 \mathrm{sec}$, followed by a cycle extension at $72{ }^{\circ} \mathrm{C}$ for $35 \mathrm{sec}$, for 33 cycles using the light strand primer L4437b (5'-AAGCAGTTGGGCCCATACC-3'; Macey et al. 1997) and heavy strand primer H5934 (5’ AGRGTGCCAATGTCTTTGTGRTT-3'; Macey et al. 1997). PCR products were purified using the AccuPrep PCR Purification Kit (Bioneer, Daejeon, Korea), and were sequenced using the amplifying primers on an ABI 3730 automatic sequencer (Applied Biosystems, CA, USA). Sequences were edited and aligned using Geneious R11 (Biomatters, Ltd, Auckland, New Zealand). All new sequences were deposited in GenBank under accession numbers MT112890MT112894 (Table 1).

\section{Phylogenetic analysis}

Homologous sequences of 69 Cnemaspis, and the outgroups Cyrtodactylus bokorensis and Hemidactylus garnotii based on Bauer et al. (2008) and Grismer et al. (2015a), were 
downloaded from GenBank and aligned to the five newly generated Cnemaspis sequences using Geneious R11 (Biomatters, Ltd, Auckland, New Zealand). The aligned dataset was partitioned into four partitions consisting of ND2 codon positions and tRNAs.

Phylogenies were reconstructed with the maximum likelihood (ML) criterion using IQ-TREE 1.6.7 (Nguyen et al. 2015) on the IQ-TREE web server (Trifinopoulos et al. 2016). The best-fit model of substitution for each partition was estimated using IQ-TREE's ModelFinder function (Kalyaanamoorthy et al. 2017) under the Akaike Information Criterion (AIC). The selected models were TIM+F+I+G4 for first, second and third codon partitions, and $\mathrm{HKY}+\mathrm{F}+\mathrm{G} 4$ for the tRNA partition. Bootstrap analysis was performed using the ultrafast bootstrap approximation (Minh et al. 2013) with 1,000 replicates and 0.95 minimum correlation coefficient.

Phylogenies were also reconstructed with Bayesian Inference (BI) in MrBayes v3.2 on XSEDE on the Cyberinfrastructure for Phylogenetic Research (CIPRES; Miller et al. 2010) computer cluster. The best-fit model of substitution was estimated for each partition with jModelTest 2.1.10 (Posada 2008) under AIC. The selected models were GTR+ I+G4 for each ND2 codon partition, and HKY+ I+G4 for the tRNA partition. Two simultaneous runs, each with three heated and one cold chain, were performed using the default priors for 10,000,000 generations, with trees sampled every 1,000 generations from the Markov Chain Monte Carlo (MCMC). Runs were halted after the average standard deviation split frequency was below 0.01 and convergence was assumed. The first $25 \%$ of the trees were discarded as burnin using the sumt command. The convergence of the two simultaneous runs, and stationary state of each parameter, were assessed by examining Trace plots and histograms in Tracer v1.6 (Rambaut et al. 2014). Runs were terminated when the effective sample sizes (ESS) of all parameters $\geq 200$.

The most likely tree in the ML analysis, and the 50\% majority-rule consensus of the sampled trees from the BI analysis, were visualized using FigTree v1.4.3 (Rambaut 2009). Nodes having bootstrap support (BS) of $\geq 95$ and posterior probabilities (PP) of $\geq 0.95$ were considered to be well-supported (Huelsenbeck and Ronquist 2001; Wilcox et al. 2002). Uncorrected pairwise genetic distances were calculated using MEGA v7.0.26 (Kumar et al. 2016).

\section{Results}

\section{Morphological analyses}

The ANOVA found statistically significant differences in morphometric characters of the Lan Saka samples and four congeners in the siamensis group $(p<0.05)$ for all fifteen variables, as did the Tukey's HSD pairwise $(p<0.05$; Table 2$)$.

The PCA of five species of Cnemaspis showed large morphometric differences on a scatter plot of the first four components with eigenvalues greater than 1.0 (Fig. 1A). 
Table 2. Pairwise matrix of significant differences (Tukey's pairwise; $p<0.05$ ) from 15 size-corrected morphometric measurements of Cnemaspis lineatubercularis sp. nov. and four congeners of the siamensis group including $C$. adangrawi, $C$. chanardi, $C$. omari, and $C$. siamensis. Measurement abbreviations are defined in the text.

\begin{tabular}{l|c|c|c|c}
\hline \multicolumn{1}{c|}{ Species } & C. lineatubercularis sp. nov. & C. adangrawi & C. chanardi & C. omari \\
\hline C. lineatubercularis sp. nov. & - & - & - & - \\
\hline C. adangrawi & SVL, FL, TBL, AG, HL, & - & - \\
& HW, EE, EL, ES, IN, IO & & - & - \\
\hline C. chanardi & TBL, TW, AG, HL, HW, EL & SVL, FL, TBL, AG, & & \\
& & ED, EE, EL, EN, ES, & & \\
& & IN, IO & & \\
\hline C. omari & FL, TBL, HW, HD, EE, & SVL, TW, FL, AG, & FL, TBL, HL, HW, \\
& ES, IO & HL, HW, EE, ED, & HD, ED, EE, ES, & \\
& & EL, IN & IN, IO & \\
\hline C. siamensis & SVL, TW, FL, TBL, AG, & SVL, TW, FL, TBL, & SVL, TW, FL, TBL, \\
& HW, ED, EE, EL, EN, ES, & AG, HL, EE, EL, EN, HL, HD, ED, EE, EL, & SV, TW, FL, TBL, \\
& IN, IO & ES, IO & EN, ES, IN, IO & EL, EN, ES \\
\hline
\end{tabular}

These four components accounted for $85.40 \%$ of the total variance (Table 3). The first principal component (PC1) accounted for $33.88 \%$ of the most of variance and loaded heavily on the head proportions (interorbital distance, eye-nostril distance and eye-snout distance) and the shape of tail (tail width). The second principal component (PC2) accounted for $25.70 \%$ and mostly loaded for the body proportion (axillar-groin length) and the head proportions (internarial distance, head length, eye-ear distance and ear length). The third principal component (PC3) accounted for $17.10 \%$ and loaded heavily on the head proportions (head width and head depth) and forearm length whereas the fourth (PC4) accounted for $8.72 \%$ and loaded heavily on the head proportions (head width, ear length and head length) and the body proportions (axillagroin length and tibia length). Factor loadings for each component are provided in Table 3. The ordination of the first two components showed separation between the Lan Saka samples and four congeners in the siamensis group. The PC2 axis showed separation between $C$. adangrawi, $C$. omari, and C. siamensis from C. chanardi and the Lan Saka samples. The biplot analysis showed that the Lan Saka samples overlapped slightly with C. chanardi. The DAPC (97.70\% of cumulative variance) discriminated among groups and supported distinct clusters that corresponded to five Cnemaspis species (Fig. 1B).

\section{Molecular analyses}

The aligned dataset contained 1,251 characters of 69 individuals of Cnemaspis and two individuals of the outgroup species. The standard deviation of split frequencies among the two simultaneous BI runs was 0.001646 . The ESS values were greater than or equal to 2,944 for all parameters. The maximum likelihood value of the best ML tree was $\ln L=-54,716.041$. The most likely ML tree and the 50\% majority rule consensus tree from the BI analysis resulted in trees with similar topologies (Fig. 2). 


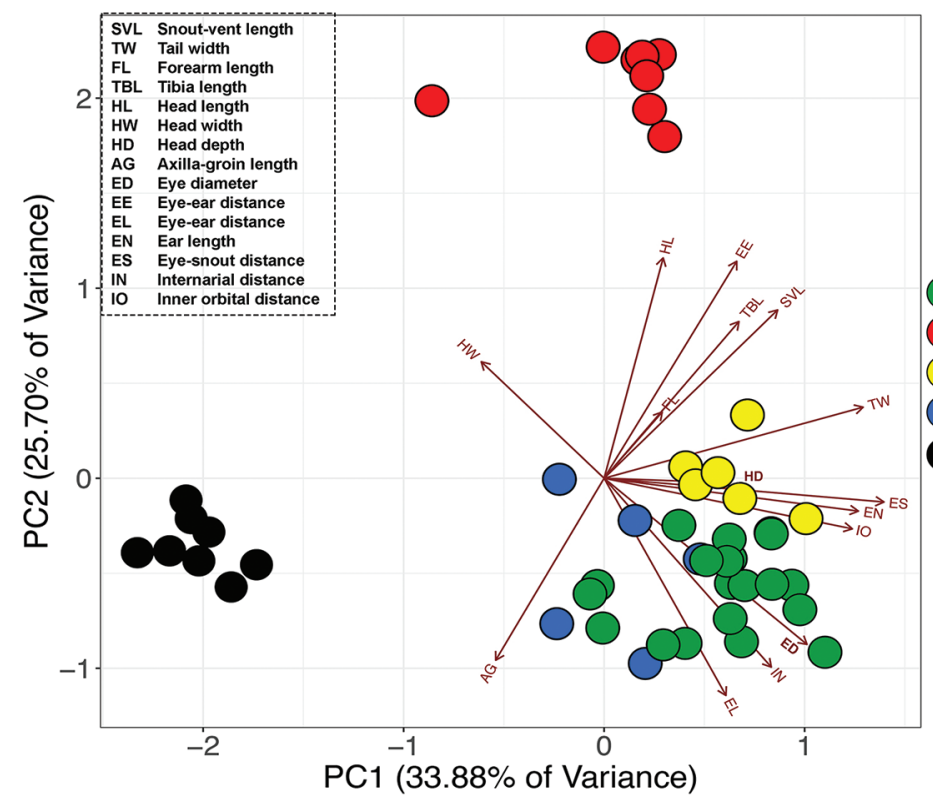

A

c. lineatubercularis sp. nov.

c. adangrawi

c. chanardi

c. omari

c. siamensis

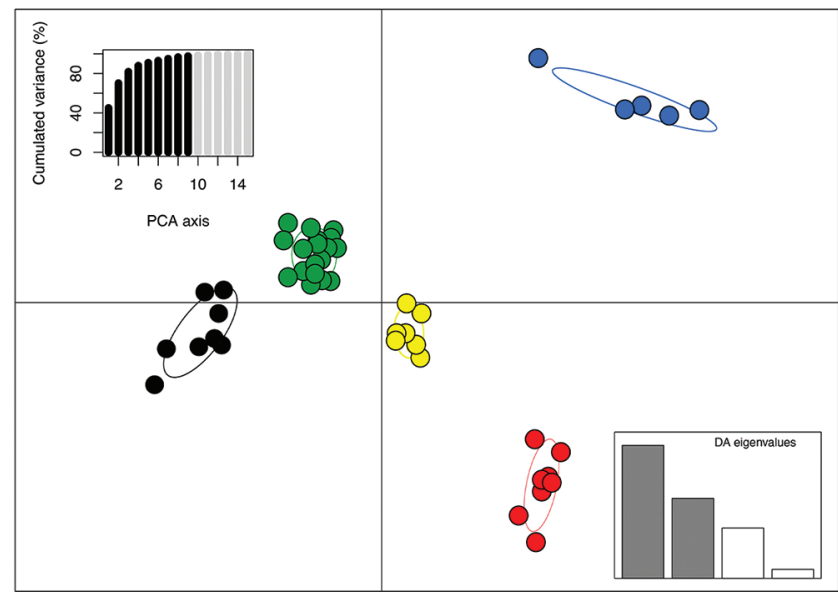

B

C. lineatubercularis sp. nov.

c. adangrawi

c. chanardi

c. omari

C. siamensis

Figure I. Results of principal component analysis (PCA), and clustering by discriminant function of principal component analysis (DAPC) of 15 morphological variables for 47 individuals of five Cnemaspis species (C. lineatubercularis sp. nov., C. adangrawi, C. chanardi, C. omari, and C. siamensis) A PCA scatter plot of PC1 and PC2 showing morphometric differentiation among five species in the siamensis group B DAPC ordination of all samples showing interspecific variation among five species in the siamensis group.

The Lan Saka samples represented a well-supported clade (100 BS, 1.0 PP) within the siamensis group and the sister taxon of a clade containing $C$. adangrawi, C. chanardi, C. phangngaensis, C. omari, and C. roticanai (Fig. 2), although relationships within that sister clade were not resolved (Fig. 2). Sequence divergences (uncorrected $p$-distance for ND2) ranged from $0.00-0.40 \%$ within the Lan Saka samples and $15.53-28.09 \%$ among the Lan Saka samples and other species in the siamensis group (Table 4). 


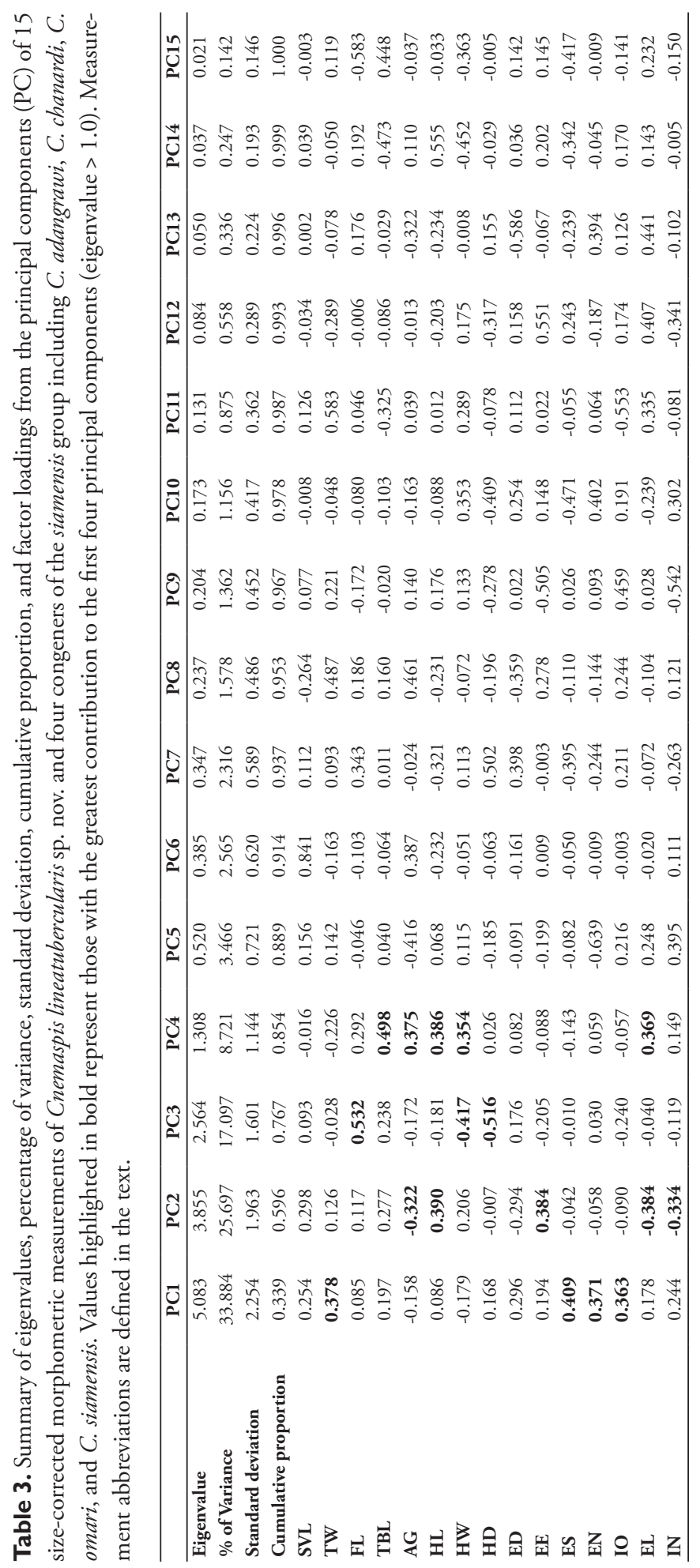




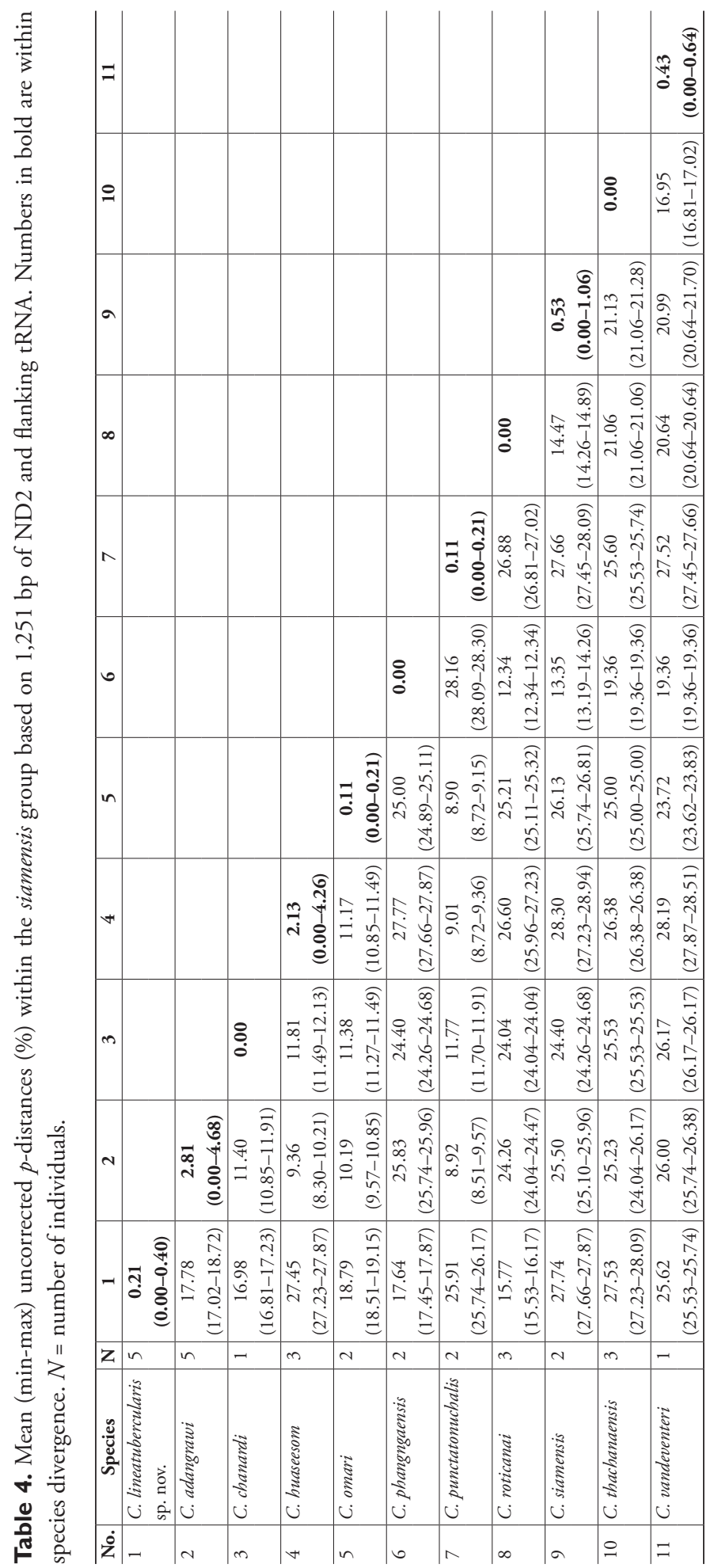



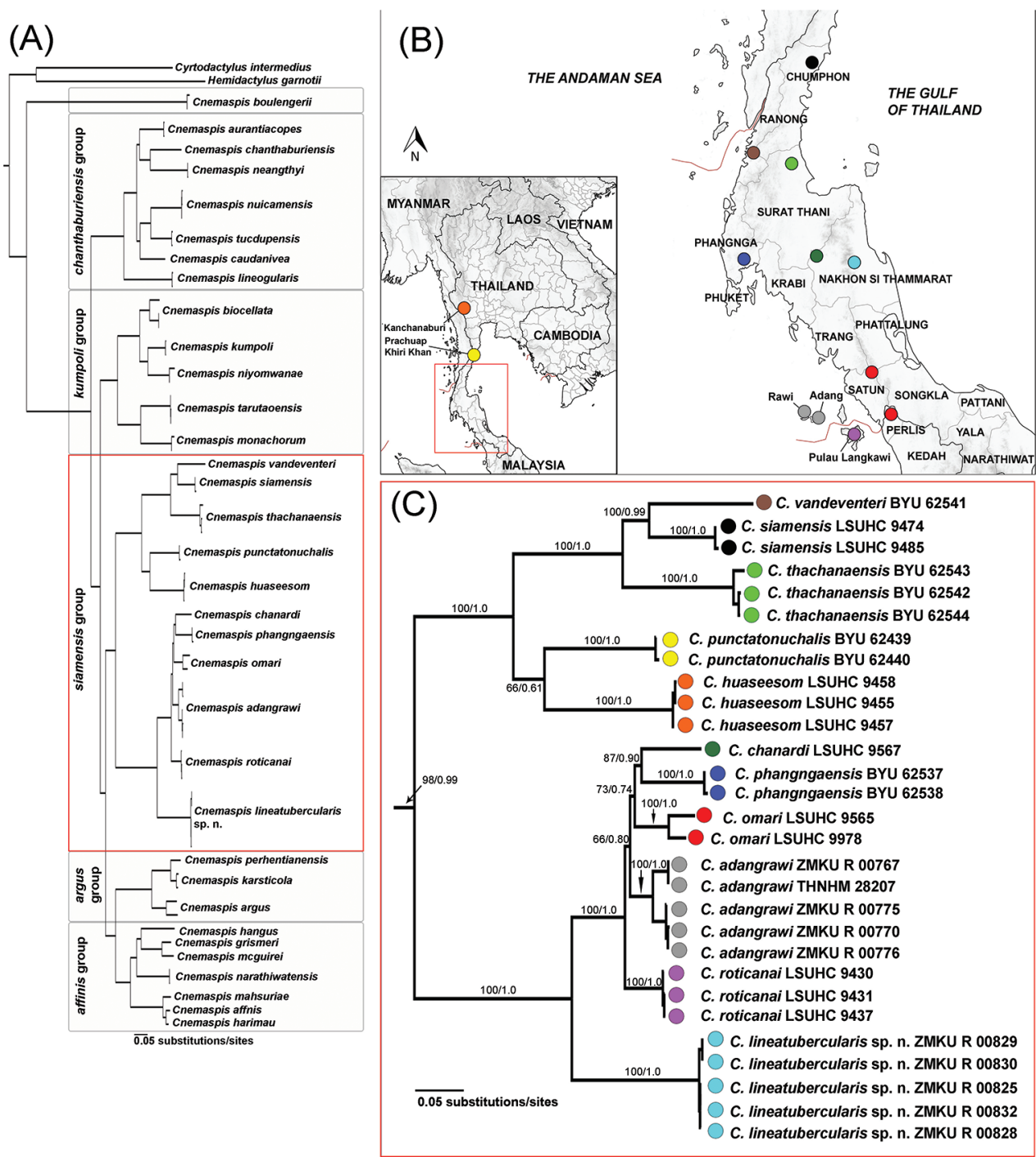

Figure 2. A The single best maximum likelihood tree of the mitochondrial NADH dehydrogenase subunit 2 (ND2) gene and flanking tRNAs from geckos of the genera Cnemaspis, Cyrtodactylus and Hemidactylus, shown in full view B map illustrating the localities of Cnemaspis siamensis group samples used in this study and $\mathbf{C}$ close-up view of the $C$. siamensis group. Support values at nodes are bootstrap values from a Maximum Likelihood analysis of the same dataset followed by posterior probabilities of the Bayesian Inference analysis.

\section{Taxonomic hypotheses}

Cnemaspis samples from Lan Saka District, Nakhon Si Thammarat Province, are diagnosable in the morphological and molecular analyses. Based on these corroborated, independent lines of evidence, we hypothesize that the Lan Saka samples represent a new species that is described as follows. 


\section{Systematics}

\section{Cnemaspis lineatubercularis sp. nov.}

http://zoobank.org/B789936F-0A24-4977-B200-4CF1D67B20FF

Lan Saka Rock Gecko

Thai common name: Jing Jok Niew Yaow Lan Saka

Figures 3-8

Type material. Holotype (Figs 3-5). ZMKU R 00828, adult male from Thailand, Nakhon Si Thammarat Province, Lan Saka District, Kam Lon Subdistrict, Wang Mai Pak Waterfall $\left(8^{\circ} 26.807^{\prime} \mathrm{N}, 99^{\circ} 46.525^{\prime} \mathrm{E}\right.$; $96 \mathrm{~m}$ a.s.l.), collected on 25 January 2019 by Natee Ampai, Anchalee Aowphol, Attapol Rujirawan, Korkwan Termprayoon and Siriporn Yodthong.

Paratypes (Figs 6-8). Eighteen paratypes (adult males $=11$, adult females $=7$ ). ZMKU R 00821-00825 (five adult males), and ZMKU R 00826 (adult female), same data as holotype except that they were collected on 25 October 2016. ZMKU R 00827, ZMKU R 00829-00831 (four adult males), ZMKU R 00832-00835 (four adult females), THNHM 28694-28695 (two adult males) and THNHM 28696-28697 (two adult females), same data as holotype.

Diagnosis. Cnemaspis lineatubercularis sp. nov. can be distinguished from all other Cnemaspis by having the following combination of characters: (1) maximum SVL of $40.6 \mathrm{~mm}$ (mean $38.8 \pm \mathrm{SD} 1.4, N=12$ ) in adult males and maximum SVL of $41.8 \mathrm{~mm}$ (mean $39.5 \pm \mathrm{SD} 1.9, N=7$ ) in adult females; (2) 8-9 supralabial and infralabial scales; (3) gular, pectoral, abdominal, and subcaudal scales keeled; (4) rostral, interorbitals, supercilium, palmar scales, and ventral scales of brachia smooth; (5) 5-6 small, subconical spine-like tubercles present on flanks (6) 19-21 paravertebral tubercles linearly arranged; (7) 27-29 subdigital lamellae under the $4^{\text {th }}$ toe; (8) 4-7 pore-bearing precloacal scales, pores rounded, arranged in chevron shape and separated in males; (9) one postcloacal tubercle each side in males; (10) ventrolateral caudal tubercles anteriorly present; (11) caudal tubercles restricted to a single paravertebral row on each side; (12) single median row of subcaudal scales keeled and lacking enlarged median row; and (13) gular region, abdomen, limbs and subcaudal region yellowish only in males. These differences are summarized among geographically close congeners in the siamensis group (Table 5).

Description of holotype. Adult male; SVL $40.1 \mathrm{~mm}$; head moderate in size (HL/ SVL 0.26), narrow (HW/SVL 0.16), flattened (HD/HL 0.41) and head distinct from neck; snout moderate (ES/HL 0.47), snout slightly concave in lateral view; postnasal region concave medially; scales of rostrum smooth, larger than conical scales on occiput; weak supraorbital ridges; gular marking absent; gular and throat scales granular, keeled and round; shallow frontorostral sulcus; canthus rostralis nearly absent, smoothly rounded; eye large (ED/HL 0.23); pupil round; extral-brillar fringe scales largest anteriorly; scales on interorbitals and supercilium smooth; ear opening oval, taller than wide; rostral slightly concave; rostral bordered posteriorly by supranasals 


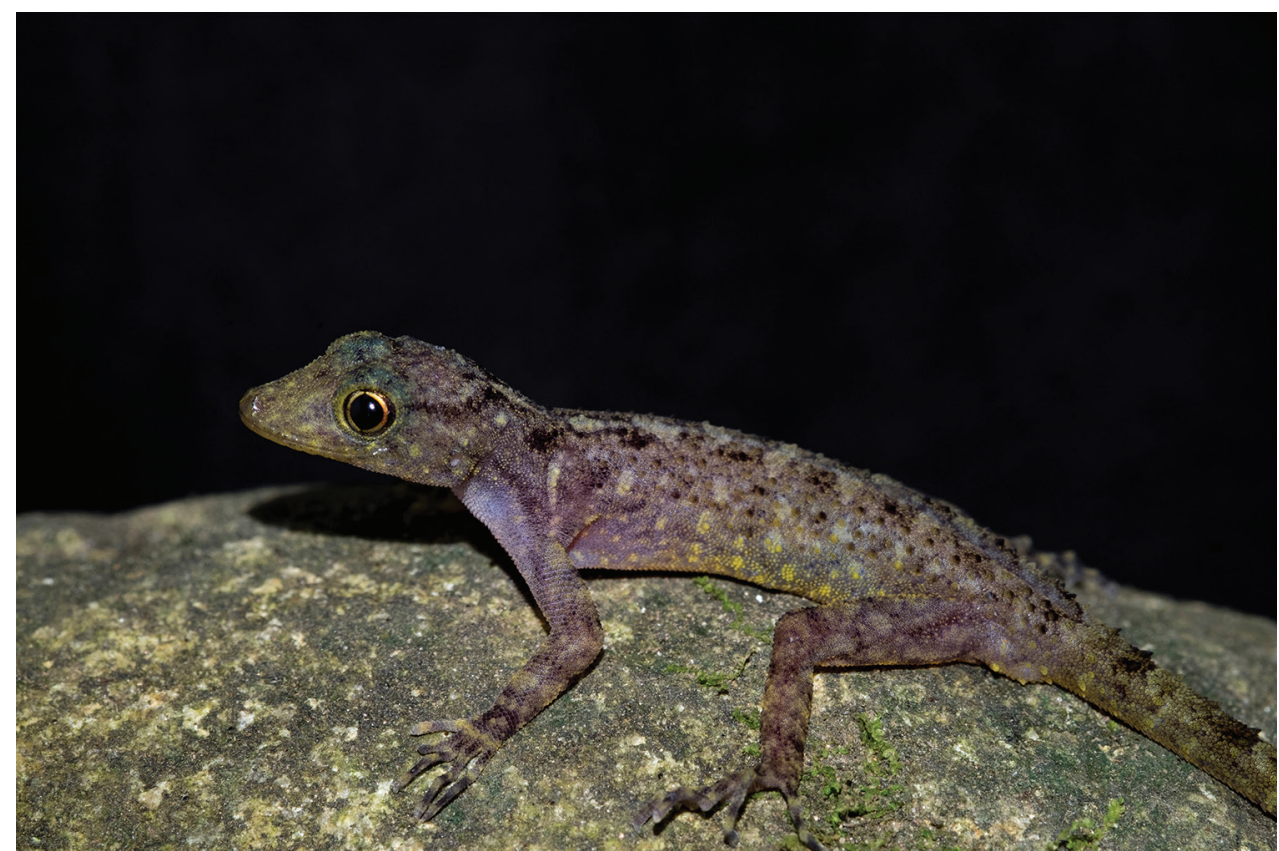

Figure 3. Male holotype (ZMKU R 00828) of Cnemaspis lineatubercularis sp. nov. from Wang Mai Pak Waterfall, Lan Saka District, Nakhon Si Thammarat Province, Thailand.

and laterally by first supralabials; 9, 9 (Right, Left) supralabials decreasing in size posteriorly; 9, 9 (Right, Left) infralabials decreasing in size posteriorly; nostril elliptical, oriented dorsoposteriorly, bordered posteriorly by small postnasal scales; mental scales large, triangular, concave, bordered posteriorly by three large postmentals.

Body slender, elongate (AG/SVL 0.43); small, keeled, dorsal scales equal in size throughout body intermixed with several large, keeled, multicarinate tubercles; 19 paravertebral tubercles linearly arranged; tubercles present on lower flanks; tubercles extend from occiput to tail; five small, subconical spine-like tubercles on flanks; dorsal scales raised and keeled; pectoral and abdominal scales keeled, round, flat to concave, slightly larger than dorsal and not larger posteriorly; ventral scales of brachia smooth, raised and juxtaposed; six separated pore-bearing precloacal scales with rounded pores; precloacal depression absent; femoral pores absent.

Fore and hind limbs moderately long, slender; scales beneath forearm slightly raised, smooth and sub-imbricate; subtibial scales keeled; palmar scales smooth and juxtaposed; digits elongate, slender, inflected joint and bearing slightly recurved claws; subdigital lamellae unnotched; lamellae beneath first phalanges wide; lamellae beneath phalanx immediately following inflection granular; lamellae of distal phalanges wide; lamellae beneath inflection large; interdigital webbing absent; enlarged submetatarsal scales on $1^{\text {st }}$ toe absent; total subdigital lamellae on fingers: 17-21-25-28-26 (right manus), 17-16 (broken)-25-28-26 (left manus); fingers increase in length from first to fourth with fourth and fifth nearly equal in length; relative length of fingers 
Table 5. Meristic character state and color pattern of species in the Cnemaspis siamensis group. Measurements are taken in millimeters and measurement abbreviations are defined in the text. Key: $-=$ data unavailable, $\mathrm{w}=$ weak.

\begin{tabular}{|c|c|c|c|c|c|c|c|c|c|c|c|c|}
\hline Characters/Species & 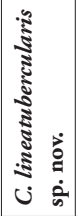 & 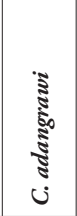 & 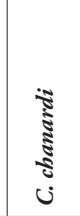 & 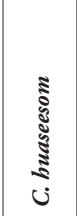 & 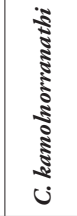 & 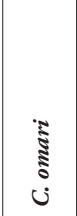 & 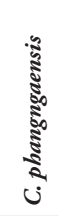 & 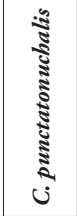 & 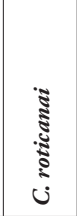 & 胥 & 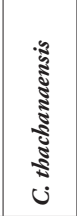 & 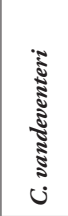 \\
\hline Sample size & 19 & 15 & 25 & 5 & 3 & 8 & 2 & 5 & 8 & 12 & 6 & 3 \\
\hline Maximum SVL & 41.8 & 44.9 & 40.9 & 43.5 & 37.8 & 41.3 & 42.0 & 49.6 & 47.0 & 39.7 & 39.0 & 44.7 \\
\hline Supralabial scales & $8-9$ & 10 & $8-10$ & $7-10$ & $8-9$ & $8-9$ & 10 & 8 & $8-9$ & $8-9$ & $10-11$ & $8-9$ \\
\hline Infralabial scales & $8-9$ & 9 & 8 & $6-9$ & $7-8$ & $7-8$ & 10 & $7-8$ & $7-8$ & $6-8$ & $9-11$ & $7-9$ \\
\hline Ventral scales keeled (1) or smooth (0) & 1 & 1 & 1 & 0 & $\mathrm{w}, 0$ & 1 & 1 & 0 & 1 & 1 & 1 & 1 \\
\hline No. of pore-bearing precloacal scales & $4-7$ & $6-8$ & $6-8$ & $5-8$ & $6-7$ & $3-6$ & 4 & 0 & $3-6$ & 0 & 0 & 4 \\
\hline $\begin{array}{l}\text { Precloacal scales pore-bearing } \\
\text { continuous ( } 1 \text { ) or separated }(0)\end{array}$ & 0 & 0 & 0 & 1 & 1 & 0 & 1 & - & 0 & - & - & 0 \\
\hline $\begin{array}{l}\text { Precloacal pores elongate (1) or } \\
\text { round }(0)\end{array}$ & 0 & 0 & 0 & 0 & 1 & 0 & 0 & - & 0 & - & - & 0 \\
\hline No. of paravertebral tubercles & $19-21$ & $23-25$ & $22-25$ & $18-24$ & $19-24$ & $22-29$ & 22 & $24-27$ & $25-27$ & $19-25$ & $15-19$ & $25-29$ \\
\hline $\begin{array}{l}\text { Paravertebral tubercles linearly } \\
\text { arranged (1) or more random }(0)\end{array}$ & 1 & 0 & 0 & $\mathrm{w}, 0$ & $\mathrm{w}$ & $\mathrm{w}, 0$ & 1 & $\mathrm{w}$ & 0 & 0 & 1 & 0 \\
\hline $\begin{array}{l}\text { Tubercles present (1) or absent (0) on } \\
\text { lower flanks }\end{array}$ & 1 & 0 & 1 & 1 & 1 & $\mathrm{w}, 1$ & 0 & 1 & 1 & 1 & 1 & 1 \\
\hline No. of $4^{\text {th }}$ toe lamellae & $27-29$ & $26-28$ & $26-29$ & $21-31$ & $24-28$ & $25-28$ & 29 & $29-31$ & $26-29$ & $24-26$ & 24 & $24-28$ \\
\hline $\begin{array}{l}\text { Ventrolateral caudal tubercles } \\
\text { anteriorly present (1) or not (0) }\end{array}$ & 1 & 1 & 0 & 0 & 0 & 0 & 1 & 1 & 0 & 0 & 1 & 0 \\
\hline $\begin{array}{l}\text { Lateral caudal furrows present (1) or } \\
\text { absent }(0)\end{array}$ & 1 & 1 & 1 & 1 & 1 & 1 & 1 & 1 & 1 & 1 & 1 & 0 \\
\hline Subcaudal keeled (1) or smooth (0) & 1 & 1 & 1 & 0 & 1 & 1 & 1 & 0 & 1 & 1 & 1 & 1 \\
\hline $\begin{array}{l}\text { Single median row of keeled } \\
\text { subcaudals (1) or smooth }(0)\end{array}$ & 1 & 1 & 0 & 0 & $\mathrm{w}$ & 0 & 1 & 0 & 0 & 0 & 1 & $\mathrm{w}$ \\
\hline $\begin{array}{l}\text { Enlarge median subcaudal scales row } \\
\text { (1) or not }(0)\end{array}$ & 0 & 0 & 1 & 0 & $\mathrm{w}$ & 0 & 0 & 1 & $\mathrm{w}$ & 1 & 0 & 1 \\
\hline $\begin{array}{l}\text { Caudal tubercles restricted to a single } \\
\text { paravertebral row } \\
\text { on each side (1) or not }(0)\end{array}$ & 1 & 0 & 0 & 0 & 0 & 0 & 1 & 0 & 0 & 0 & 1 & 0 \\
\hline No. of postcloacal tubercles in males & 1 & 1 & 1 & $1-2$ & $1-2$ & 1 & 2 & $1-3$ & $1-2$ & $1-2$ & 0 & $1-3$ \\
\hline Subtibial scales keeled (1) or smooth (0) & 1 & 1 & 1 & 0 & 0,1 & 1 & 1 & 1 & 1 & 1 & 1 & 1 \\
\hline $\begin{array}{l}\text { Subcaudal region yellow present (1) } \\
\text { or not }(0)\end{array}$ & 1 & 0 & 1 & 1 & 0 & 1 & 1 & 0 & 1 & 0 & 0 & 0 \\
\hline $\begin{array}{l}\text { Ventral pattern sexually dimorphic } \\
\text { present }(1) \text { or not }(0)\end{array}$ & 1 & 1 & 1 & 1 & - & 1 & 1 & 1 & 1 & 1 & 1 & 1 \\
\hline $\begin{array}{l}\text { Dorsal color pattern sexually } \\
\text { dimorphic (1) or not }(0)\end{array}$ & 0 & 0 & 0 & 1 & 0 & 0 & 1 & 1 & 1 & 0 & 0 & 0 \\
\hline
\end{tabular}

IV $>$ V $>$ III $>$ II $>$ I; total subdigital lamellae on toes: 13-21-24-29-25 (right pes), 13-2124-29-25 (left pes); toes increase in length from first to fifth with fourth and fifth nearly equal in length; relative length of toes $\mathrm{IV}>\mathrm{V}>\mathrm{III}>\mathrm{II}>\mathrm{I}$.

The original tail cylindrical, swollen at the base and longer than head and body (TL/SVL 1.36); subcaudal scales keeled, juxtaposed, similar to dorsal scale of the tail size; shallow, middorsal furrow; deeper lateral caudal furrow present; enlarged, trans- 
verse caudal tubercles arranged in segmented whorls, not encircling tail; enlarged median subcaudal scale row absent; caudal tubercles absent from lateral furrow; tail length (TL) $54.7 \mathrm{~mm}$; a single postcloacal tubercle on each side at lateral surface of hemipenial swellings at the base of tail.

Measurements of holotype (in mm; Table 6). SVL 40.1; TL (original) 54.7; TW 3.9; FL 5.8; TBL 7.2; AG 17.4; HL 10.3; HW 6.3; HD 4.2; ED 2.4; EE 3.1; ES 4.8; EN 3.9; IO 2.9; EL 1.0; IN 1.0.

Coloration in life (Fig. 4). Dorsal ground color of head light brown, top of head bearing small, diffuse, faint black and yellowish markings; dark postorbital stripes faint, extending to nape; large, round, whitish marking on nape; single light-yellowish prescapular crescent on the shoulder, located dorsoanteriorly of forelimb insertion; dorsal ground color of body, limbs and tail light brown with black irregular blotches; ground color of ventral surfaces grayish-white intermixed with yellowish blotches; ventral pattern sexually dimorphic, anterior gular, abdominal, and caudal regions yellowish in males; two dark blotches on nape form a bipartite pattern; light sage vertebral blotches extending from the nape to tail; flanks with irregular, incomplete brown to yellowish blotches becoming smaller posteriorly; tubercles on the whole body white or yellow; widely separated, white or yellow tubercles occur on flanks; subconical spine-like yellowish tubercles on flanks; limbs beige with dark brown mottling; tail faintly marked with dark brown.

Coloration in preservative (Figs 5, 7, 8). Color pattern similar to that in life with some fading of markings. Dorsal ground color of head, body, limbs and tail darker brown than in life, with indistinct, irregular markings. Yellow coloration in gular, pectoral, abdominal regions, flanks, and tail faded to light-yellow and creamy-white.

Variation. Most paratypes approximate the holotype in general aspects of morphology (Figs 6-8), with most differences found in the degree of vertebral blotches. All adult female paratypes lack the yellowish coloration in the gular, abdominal, and caudal regions. ZMKU R 00821-00825, ZMKU R 00829-00831, THNHM 28694 (nine adult males) and ZMKU R 00826, ZMKU R 00832 and ZMKU R 00833 (three adult females) have regenerated tails of uniform tan coloration. ZMKU R 00821, 00824, 00827 (three adult males) and ZMKU R 00832, 00835 (two adult females) have lighter dorsal markings that appear more as transverse bands than as paravertebral blotches. THNHM 28696 (adult female) has a broken tail. Differences in meristic and morphometric characters within the type series are presented in Table 6.

Distribution and natural history. Cnemaspis lineatubercularis sp. nov. is known only from Wang Mai Pak Waterfall (96 m a.s.l.), Kam Lon Subdistrict, Lan Saka District, Nakhon Si Thammarat Province, southern Thailand (Fig. 9). The type locality is surrounded by lowland evergreen forest along a river basin in the southern part of the Nakhon Si Thammarat mountain range. Specimens were found only along granitic rocky streams of Wang Mai Pak Waterfall. The rocky boulder microhabitats of this species are dry with cool surface temperatures $\left(24.8-26.7^{\circ} \mathrm{C}, 73.2-86.1 \%\right.$ relative humidity). When disturbed, some individuals retreated deeper into rock crevices, cracks, more shaded areas or beneath rock boulders. 


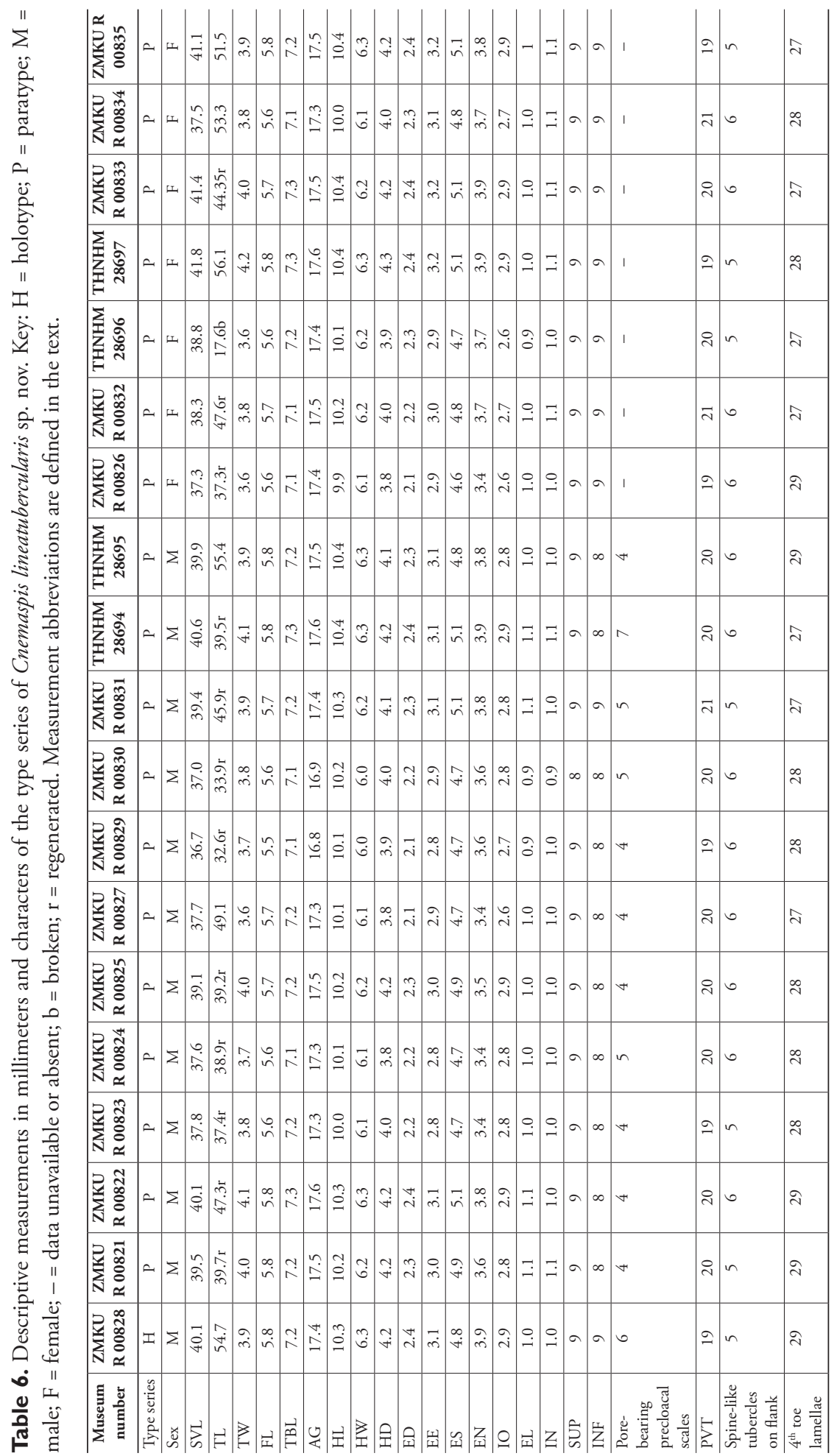




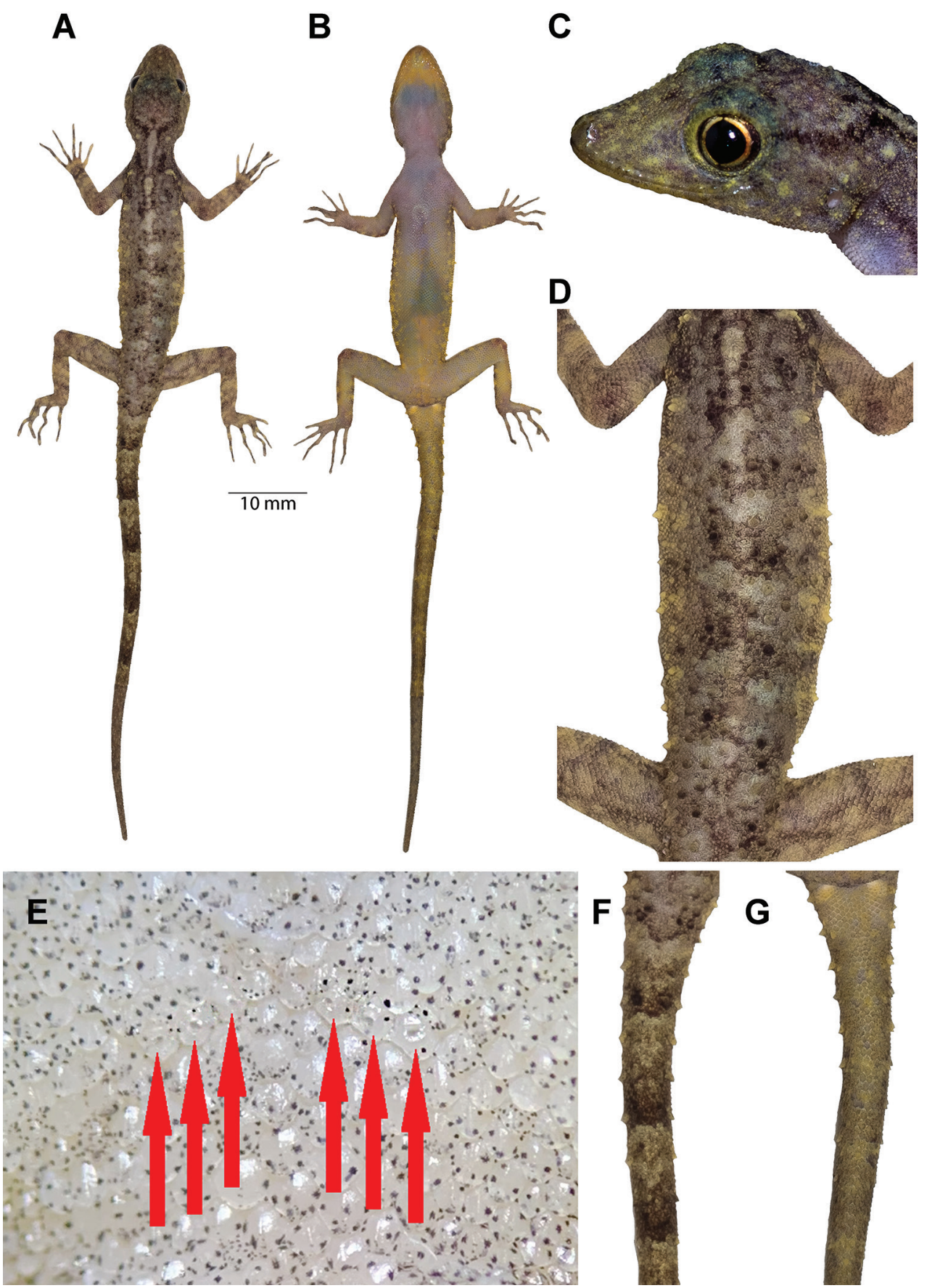

Figure 4. Male holotype (ZMKU R 00828) of Cnemaspis lineatubercularis sp. nov. from Wang Mai Pak Waterfall, Lan Saka District, Nakhon Si Thammarat Province, Thailand, in life A dorsal view B ventral view $\mathbf{C}$ lateral view of the head $\mathbf{D}$ dorsal view of trunk $\mathbf{E}$ precloacal region showing distribution of pore-bearing scales (red arrows) $\mathbf{F}$ dorsal view of tail $\mathbf{G}$ ventral view of tail. Scale bar: $10 \mathrm{~mm}$ (in dorsal and ventral views). 

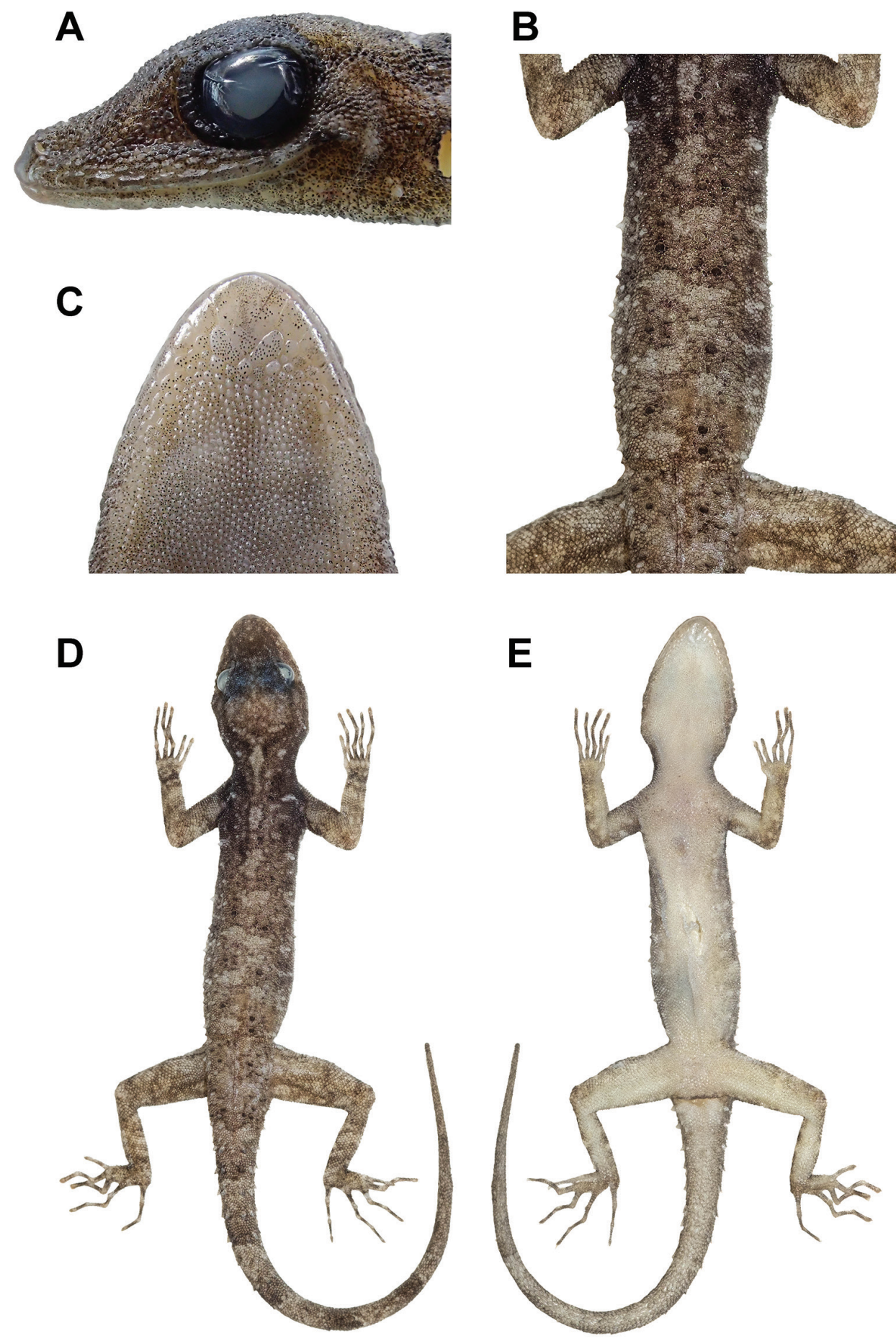

Figure 5. Male holotype (ZMKU R 00828) of Cnemaspis lineatubercularis sp. nov. from Wang Mai Pak Waterfall, Lan Saka District, Nakhon Si Thammarat Province, Thailand, in preservative A lateral view of head $\mathbf{B}$ dorsal view of trunk $\mathbf{C}$ ventral view of chin $\mathbf{D}$ dorsal view $\mathbf{E}$ ventral view. Scale bar: $10 \mathrm{~mm}(\mathbf{D}, \mathbf{E})$. 

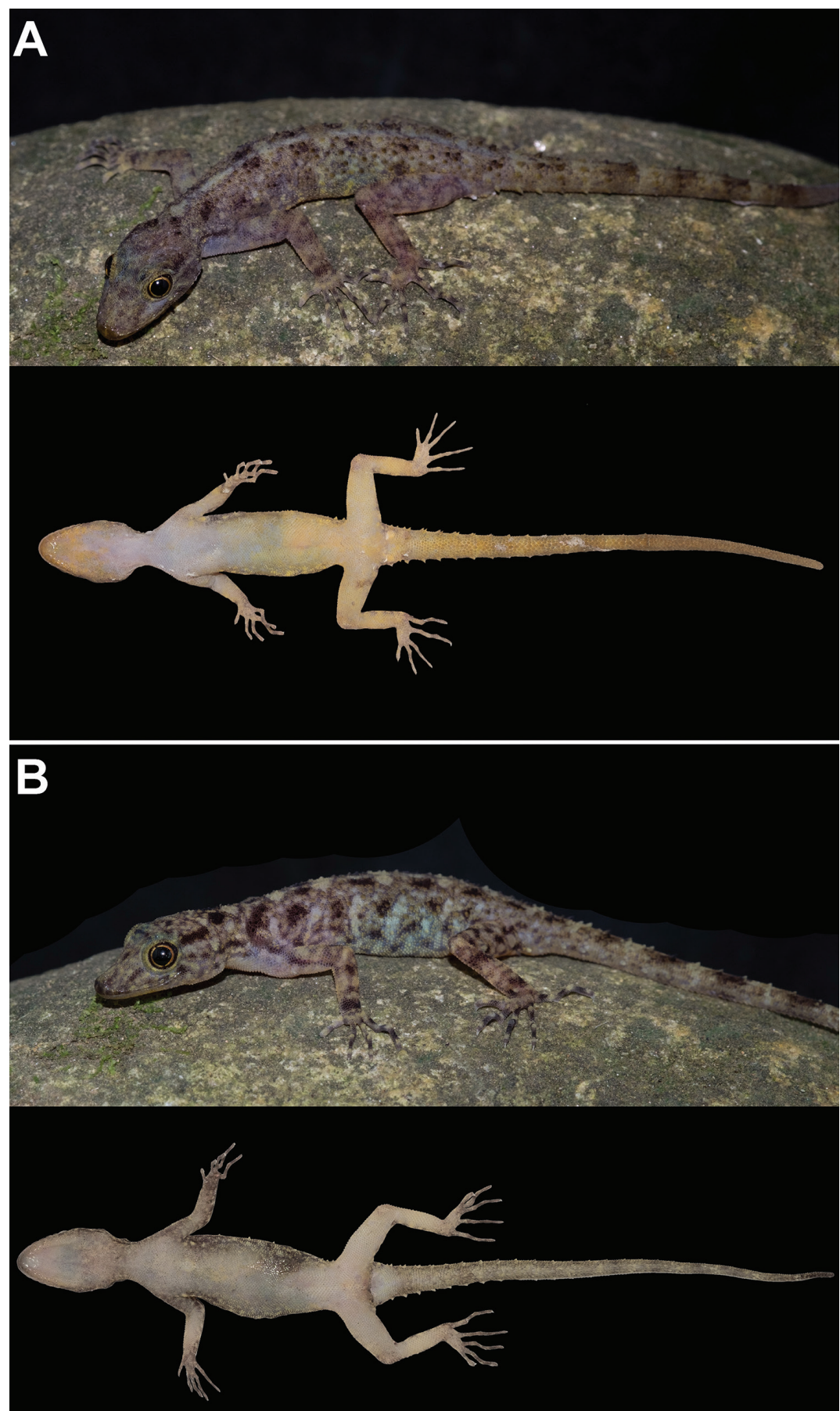

Figure 6. Coloration of Cnemaspis lineatubercularis sp. nov. in dorsal (above) and ventral (below) views of A male paratype ZMKU R 00830 and B female paratype ZMKU R 00835. Note yellowish ventral coloration that is present in males but absent in females. 
A
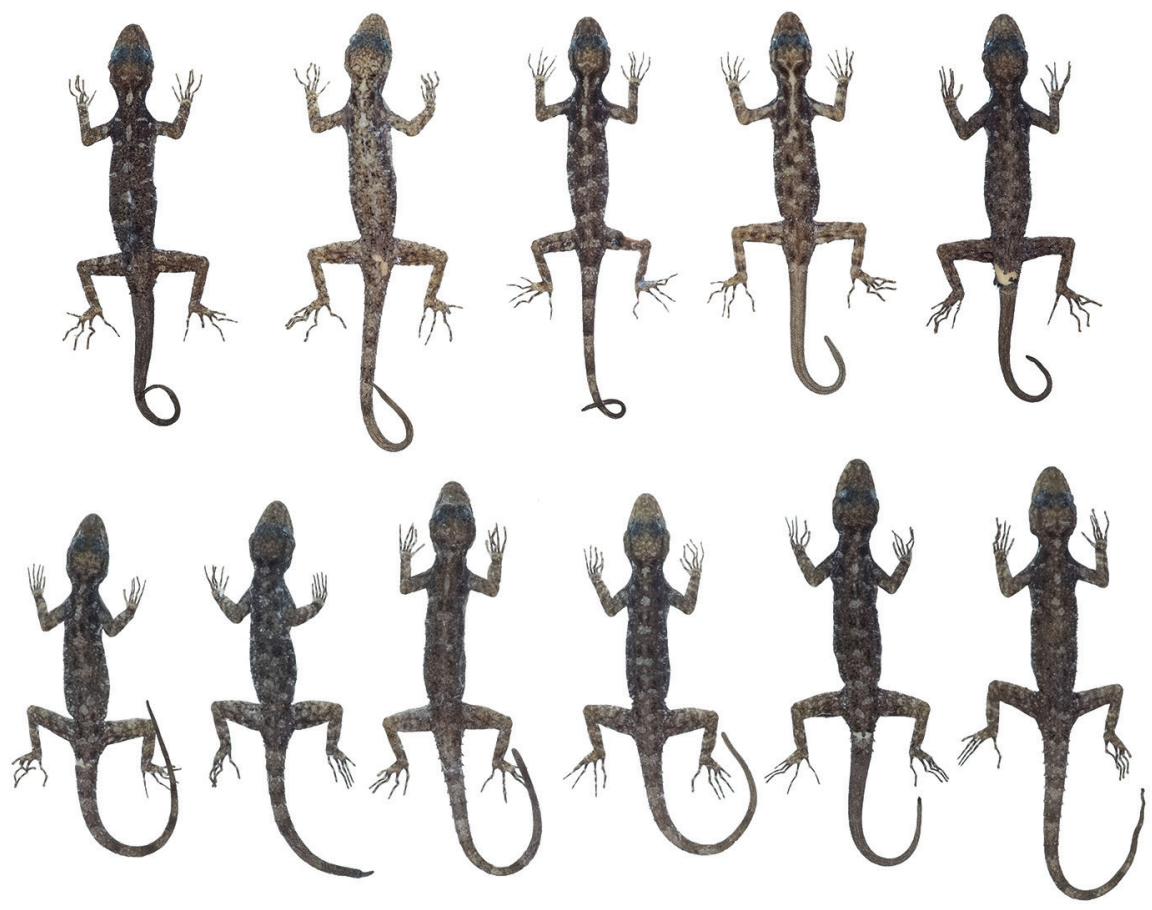

B
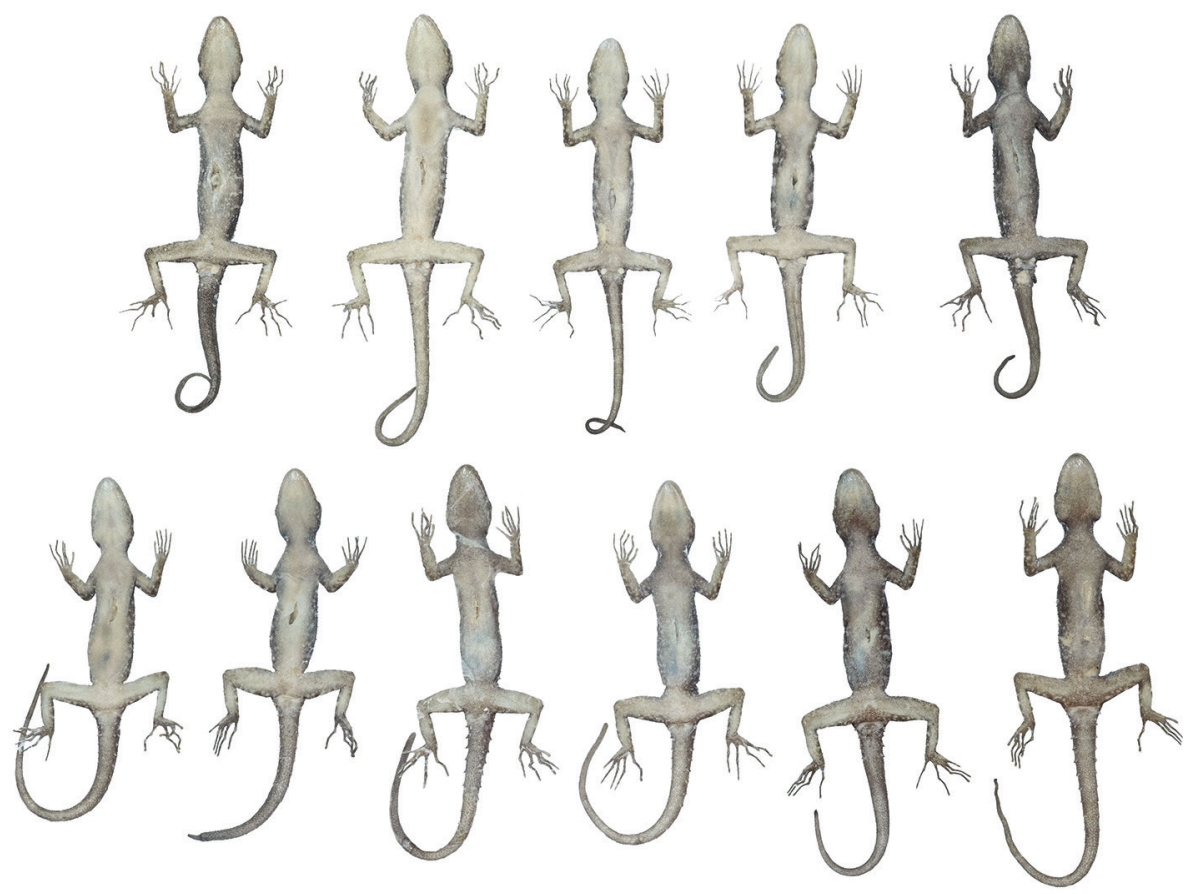

Figure 7. Male paratypes of Cnemaspis lineatubercularis sp. nov. in preservative in A dorsal view $\mathbf{B}$ ventral view; from left to right, top panel: ZMKU R 00821, ZMKU R 00822, ZMKU R 00823, ZMKU R 00824 and ZMKU R 00825; bottom panel: ZMKU R 00827, ZMKU R 00829, ZMKU R 00830, ZMKU R 00831, THNHM 28694 and THNHM 28695. 
A

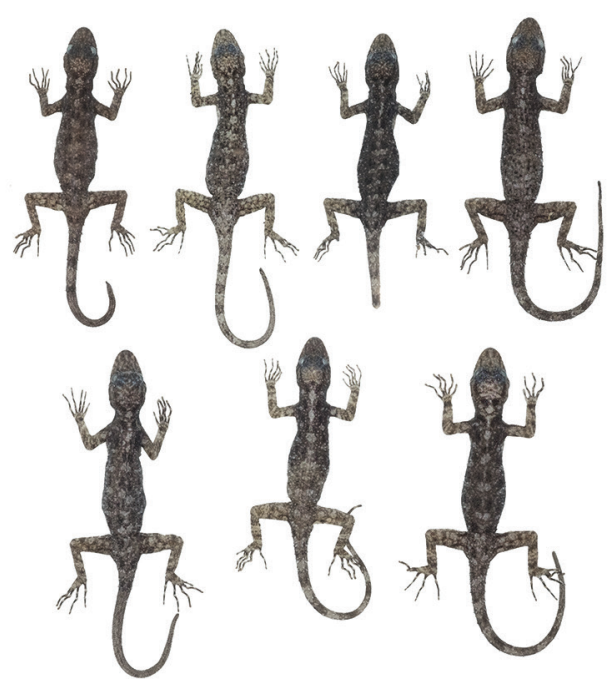

B
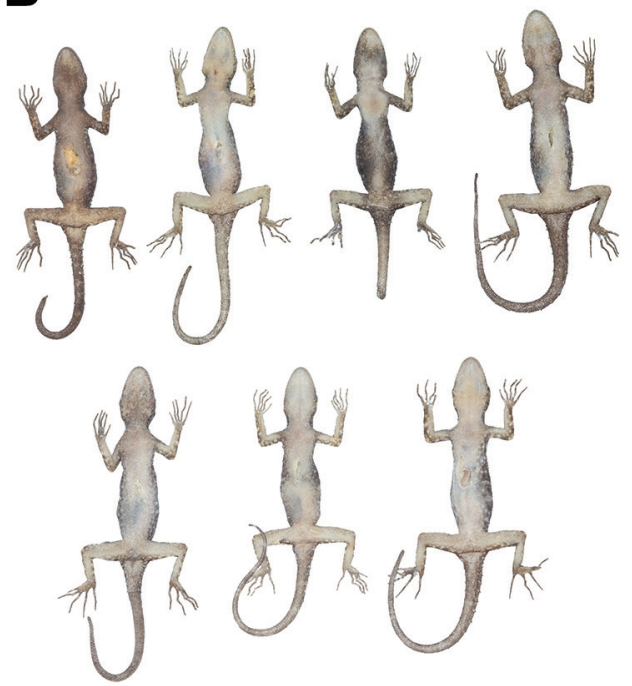

Figure 8. Female paratypes of Cnemaspis lineatubercularis sp. nov. in preservative in A dorsal view B ventral view; from left to right, top panel: ZMKU R 00826, ZMKU R 00832, THNHM 28696 and THNHM 28697; bottom panel: ZMKU R 00833, ZMKU R 00834 and ZMKU R 00835.

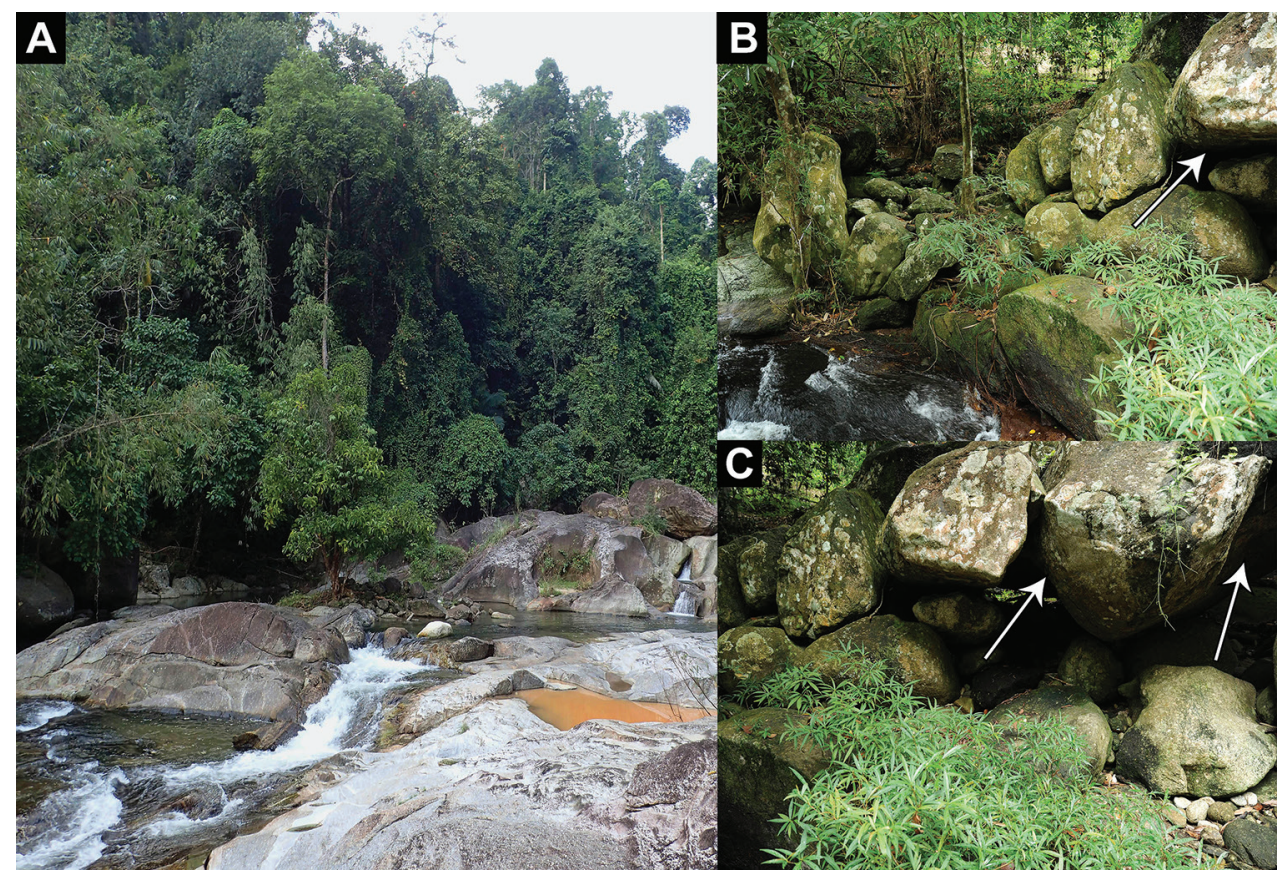

Figure 9. Habitats of Cnemaspis lineatubercularis sp. nov A Wang Mai Pak Waterfall at type locality B microhabitat of holotype in granitic rocky stream (white arrow) $\mathbf{C}$ microhabitat of paratypes in granitic rocky outcrops (white arrows) at Wang Mai Pak Waterfall, Lan Saka District, Nakhon Si Thammarat Province, Thailand. 
Seven specimens (ZMKU R 00822-00825, ZMKU R 00827, THNHM 2869628697) were collected during the day (1650-1847 h) and 12 specimens (ZMKU R 00821, ZMKU 00826, ZMKU R 00828-00832, THNHM 28694-28695 and ZMKU R 00833-00835) were collected at night (1913-1951 h).

The male holotype was found during the night $(1943 \mathrm{~h})$ perched head down on a vertical surface in a crevice of a granitic rock boulder near a stream. A female paratype (ZMKU R 00832) was found with the male holotype, separated by only a distance of approximately $10 \mathrm{~cm}$.

Paratypes that were found during the day were in shaded areas, crevices of boulders, rock walls and on boulder outcrops near streams. Paratypes found at night were in shaded surfaces of the boulders, within deep crevices, or perched on vegetation near a rocky stream. Three gravid females (ZMKU R 00832-00834) contained one or two eggs during January 2019. Some juveniles (SVL $<30 \mathrm{~mm}$; not collected) were found in rock cracks and perched on a rock near a stream on 25 January 2019.

Cnemaspis lineatubercularis sp. nov. appears to be a diurnal species in that observed specimens during daytime were active and fast-moving when disturbed, but those at night were inactive, slow-moving or asleep on dry granitic rocks and vegetations. At night, Cyrtodactylus lekaguli and Gehyra mutilata were found in syntopy with the new species on a rock wall and vegetation near a stream. A summary of ecological parameters of activity periods, elevation (lowland $<600 \mathrm{~m}$ ), microhabitat preference and presence or absence of ocelli (eyespots) of Cnemaspis in Thailand is shown in Table 7.

Etymology. The specific epithet lineatubercularis is taken from linea (Lat. for line) and tubercularis (Lat. for having tubercles), in reference to the new species having paravertebral tubercles linearly arranged.

Comparisons. Cnemaspis lineatubercularis sp. nov. can be distinguished from other members of the siamensis group (C. adangrawi, C. chanardi, C. huaseesom, C. kamolnorranathi, C. omari, C. phangngaensis, C. punctatonuchalis, C. roticanai, C. siamensis, C. thachanaensis, and $C$. vandeventeri; Table 5) by having a smaller maximum SVL of $41.8 \mathrm{~mm}$ (vs. $44.9 \mathrm{~mm}$ in C. adangrawi, $43.5 \mathrm{~mm}$ in C. huaseesom, $42.0 \mathrm{~mm}$ in $C$. phangngaensis, $49.6 \mathrm{~mm}$ in C. punctatonuchalis, $47.0 \mathrm{~mm}$ in C. roticanai, $44.7 \mathrm{~mm}$ in C. vandeventeri) and by having a larger maximum SVL $41.8 \mathrm{~mm}$ (vs. $40.9 \mathrm{~mm}$ in C. chanardi, $37.8 \mathrm{~mm}$ in C. kamolnorranathi, $41.3 \mathrm{~mm}$ in C. omari, $39.7 \mathrm{~mm}$ in C. siamensis, $39.0 \mathrm{~mm}$ in $C$. thachanaensis).

Cnemaspis lineatubercularis sp. nov. is distinguished from C. adangrawi, C. phangngaensis, and $C$. thachanaensis by having fewer 8-9 supralabial scales (vs. 10 in $C$. adangrawi and C. phangngaensis, 10-11 in C. thachanaensis). This species is distinguished from C. phangngaensis by having fewer 8-9 infralabial scales (vs. 10 in C. phangngaensis). This species is distinguished from $C$. huaseesom and $C$. punctatonuchalis by having keeled ventral scales (vs. smooth ventral scales in C. huaseesom and C. punctatonuchalis). This species is distinguished from C. punctatonuchalis, C. siamensis, and C. thachanaensis by presence of precloacal pores (vs. precloacal pores absent in $C$. punctatonuchalis, $C$. siamensis, $C$. thachanaensis). This species is distinguished from $C$. huaseesom, $C$. kamolnorranathi, and $C$. phangngaensis by having a separated row of precloacal pores 
Table 7. Ecological parameters of activity period, elevation (lowland $<600 \mathrm{~m}$ ), microhabitat preference and presence or absence of ocelli (eyespots) in 18 species of Cnemaspis in Thailand based on this and previous studies (Grismer et al. 2010, 2014; Wood et al. 2017; Ampai et al. 2019).

\begin{tabular}{|c|c|c|c|c|c|c|c|c|c|c|c|}
\hline \multirow{2}{*}{$\begin{array}{c}\text { Species/ } \\
\text { Parameters }\end{array}$} & \multicolumn{2}{|c|}{ Activity period } & \multicolumn{2}{|c|}{ Elevation } & \multicolumn{4}{|c|}{ Microhabitat preference } & \multicolumn{3}{|c|}{ Ocelli location } \\
\hline & Diurnal & Nocturnal & Lowland & Upland & Granite & Limestone & Vegetation & Terrestrial & Head & Neck & Shoulders \\
\hline \multicolumn{12}{|l|}{ affinis group } \\
\hline C. narathiwatensis & $\mathrm{x}$ & & $\mathrm{x}$ & $\mathrm{x}$ & $\mathrm{x}$ & & & & & & \\
\hline \multicolumn{12}{|c|}{ chanthaburiensis group } \\
\hline C. chanthaburiensis & & $\mathrm{x}$ & $\mathrm{x}$ & $\mathrm{x}$ & & & & $\mathrm{x}$ & & & \\
\hline C. lineogularis & $\mathrm{x}$ & & $\mathrm{x}$ & & & $\mathrm{x}$ & & & & & \\
\hline \multicolumn{12}{|l|}{ kumpoli group } \\
\hline C. biocellata & $\mathrm{x}$ & & $\mathrm{x}$ & & & $\mathrm{x}$ & & & $\mathrm{x}$ & $\mathrm{x}$ & $\mathrm{x}$ \\
\hline C. kumpoli & & $\mathrm{x}$ & $\mathrm{x}$ & & $\mathrm{x}$ & & & & & & $\mathrm{x}$ \\
\hline C. niyomwanae & & $\mathrm{x}$ & $\mathrm{x}$ & & & $\mathrm{x}$ & & & & & \\
\hline C. tarutaoensis & $\mathrm{x}$ & & $\mathrm{x}$ & & & $\mathrm{x}$ & & & & & \\
\hline siamensis group & & & & & & & & & & & \\
\hline $\begin{array}{l}\text { C. lineatubercularis } \\
\text { sp. nov. }\end{array}$ & $\mathrm{x}$ & & $\mathrm{x}$ & & $\mathrm{x}$ & & $\mathrm{x}$ & & & & \\
\hline C. adangrawi & $\mathrm{x}$ & & $\mathrm{x}$ & & $\mathrm{x}$ & & $\mathrm{x}$ & & & & \\
\hline C. chanardi & $\mathrm{x}$ & & $\mathrm{x}$ & & $\mathrm{x}$ & & $\mathrm{x}$ & & & & \\
\hline C. huaseesom & & $\mathrm{x}$ & $\mathrm{x}$ & & & $\mathrm{x}$ & & & & & \\
\hline C. kamolnorranathi & & $\mathrm{x}$ & $\mathrm{x}$ & & $\mathrm{x}$ & $\mathrm{x}$ & $\mathrm{x}$ & $\mathrm{x}$ & & & \\
\hline C. omari & $\mathrm{x}$ & & $\mathrm{x}$ & & & & $\mathrm{x}$ & & & & \\
\hline C. phangngaensis & $\mathrm{x}$ & & $\mathrm{x}$ & & & $\mathrm{x}$ & $\mathrm{x}$ & & & & \\
\hline C. punctatonuchalis & & $\mathrm{x}$ & $\mathrm{x}$ & & $\mathrm{x}$ & & & & & $\mathrm{x}$ & $\mathrm{x}$ \\
\hline C. siamensis & $\mathrm{x}$ & & $\mathrm{x}$ & & & & $\mathrm{x}$ & & & & \\
\hline C. thachanaensis & $\mathrm{x}$ & & $\mathrm{x}$ & & & $\mathrm{x}$ & $\mathrm{x}$ & & & & \\
\hline C. vandeventeri & & $\mathrm{x}$ & $\mathrm{x}$ & & $\mathrm{x}$ & & $\mathrm{x}$ & & & & \\
\hline
\end{tabular}

(vs. continuous in C. huaseesom, C. kamolnorranathi, C. phangngaensis). This species is distinguished from C. kamolnorranathi by having rounded precloacal pores (vs. pores elongated in C. kamolnorranathi).

Cnemaspis lineatubercularis sp. nov. is distinguished from C. adangrawi, C. chanardi, C. omari, C. phangngaensis, C. punctatonuchalis, C. roticanai, and C. vandeventeri by having fewer 19-21 paravertebral tubercles (vs. 23-25 in C. adangrawi, 22-25 in C. chanardi, 22-29 in C. omari, 22 in C. phangngaensis, 24-27 in C. punctatonuchalis, 25-27 in C. roticanai, 25-29 in C. vandeventeri). This species is distinguished from $C$. adangrawi, C. chanardi, C. huaseesom, C. omari, C. roticanai, C. siamensis, and C. vandeventeri by having paravertebral tubercles linearly arranged (vs. randomly arranged in $C$. adangrawi, C. chanardi, C. huaseesom, C. omari, C. roticanai, C. siamensis, $C$. vandeventeri). This species is distinguished from $C$. adangrawi and $C$. phangngaensis by having tubercles on lower flanks (vs. absent in $C$. adangrawi and $C$. phangngaensis). This species is distinguished from $C$. siamensis and $C$. thachanaensis by having more 27-29 lamellae under $4^{\text {th }}$ toe (vs. 24-26 in C. siamensis and 24 in C. thachanaensis).

Cnemaspis lineatubercularis sp. nov. is distinguished from C. chanardi, C. huaseesom, C. kamolnorranathi, C. omari, C. roticanai, C. siamensis, and $C$. vandeventeri by the presence of ventrolateral caudal tubercles anteriorly (vs. lacking in $C$. chanardi, $C$. huaseesom, C. kamolnorranathi, C. omari, C. roticanai, C. siamensis, C. vandeventeri). This species is distinguished from $C$. vandeventeri by having lateral caudal furrows (vs. 
lacking in C. vandeventeri). This species is distinguished from $C$. huaseesom and $C$. punctatonuchalis by having keeled subcaudal scales (vs. lacking in $C$. huaseesom and C. punctatonuchalis). This species is distinguished from C. chanardi, C. huaseesom, $C$. omari, $C$. punctatonuchalis, $C$. roticanai, and $C$. siamensis by having single median row of keeled subcaudals (vs. lacking in C. chanardi, C. huaseesom, C. omari, C. punctatonuchalis, C. roticanai, C. siamensis). This species is distinguished from C. chanardi, $C$. punctatonuchalis, $C$. siamensis, and $C$. vandeventeri by lacking enlarged median subcaudal scales (vs. present in C. chanardi, C. punctatonuchalis, C. siamensis, C. vandeventeri). This species is distinguished from $C$. adangrawi, C. chanardi, C. huaseesom, C. kamolnorranathi, C. omari, C. punctatonuchalis, C. roticanai, C. siamensis, and C. vandeventeri by having caudal tubercles restricted to a single paravertebral row on each side (vs. lacking in C. adangrawi, C. chanardi, C. huaseesom, C. kamolnorranathi, $C$. omari, C. punctatonuchalis, C. roticanai, C. siamensis, C. vandeventeri).

Cnemaspis lineatubercularis sp. nov. is distinguished from $C$. thachanaensis by having one postcloacal tubercle in males (vs. lacking in C. thachanaensis). This species is distinguished from $C$. huaseesom by having keeled subtibial scales (vs. smooth in $C$. huaseesom). This species is distinguished from C. adangrawi, C. kamolnorranathi, C. punctatonuchalis, $C$. siamensis, $C$. thachanaensis, and $C$. vandeventeri by having yellow coloration in the subcaudal region (vs. lacking in $C$. adangrawi, C. kamolnorranathi, C. punctatonuchalis, C. siamensis, C. thachanaensis, C. vandeventeri). This species is distinguished from C. huaseesom, C. phangngaensis, C. punctatonuchalis, and C. roticanai by lacking dorsal color pattern sexually dimorphic (vs. having in $C$. huaseesom, $C$. phangngaensis, C. punctatonuchalis, C. roticanai).

\section{Discussion}

The complex geological history of Thailand created a large number of granitic rocky outcrop ecosystems in southern Thailand (Charusiri 1993; Cobbing et al. 2011). This ecosystem supports high levels of species endemism and species diversity of gekkonid lizards, especially species in the genus Cnemaspis (see figure 5 in Grismer et al. 2014). The findings of this study provide new data from a poorly studied area in Nakhon $\mathrm{Si}$ Thammarat Province, southern Thailand. The results suggest that additional unexplored regions may still harbor unrecognized species of Cnemaspis in Thailand.

A decade ago, only four species of Cnemaspis were known from Thailand, including C. biocellata, C. chanthaburiensis, C. kumpoli, and C. siamensis (Smith 1925; Taylor 1963; Bauer and Das 1998; Grismer et al. 2008a, b). Grismer et al. (2010) described seven new species of Cnemaspis (C. chanardi, C. huaseesom, C. kamolnorranathi, C. narathiwatensis, C. niyomwanae, C. punctatonuchalis, and C. vandeventeri) from Thailand. Previously, Grismer et al. (2014) described a new species C. omari from Perlis, Malaysia, that is also distributed in adjacent Satun Province, Thailand. Wood et al. (2017) described three additional new species of Cnemaspis (C. lineogularis, C. phangngaensis, and $C$. thachanaensis) from southern Thailand. Most recently, two new insular species of Cnemaspis (C. adangrawi and C. tarutaoensis) were described from Tarutao, Adang 
and Rawi islands of southern Thailand (Ampai et al. 2019). The discovery and description of $C$. lineatubercularis sp. nov. brings the total number of Thai Cnemaspis species to 18 , representing one-third (33\%) of the 60 named species in Southeast Asia.

The new species is known only from the type locality and likely has a narrow geographic distribution. It is expected to be found in other nearby granitic rocky streams in Kam Lon Subdistrict, Lan Saka District, Nakhon Si Thammarat Province. However, additional surveys for this species are needed to clarify the geographic range of the new species. Our findings agree with those of Grismer et al. (2014) that most species of Cnemaspis in Thailand are diurnal, granite-associated, lowland species that lack ocelli (Table 7). Further research and additional field surveys in unexplored regions of lowland forest in southern Thailand are needed to better understand the taxonomy, ecology, distribution, biogeography, and conservation of Cnemaspis in the region.

\section{Acknowledgments}

This work was supported by grants from the Thailand Research Fund (DBG6080010) and the Center of Excellence on Biodiversity (BDC), Office of Higher Education Commission (BDC-PG-160022). AA was supported by Department of Zoology and International SciKU Branding (ISB), Faculty of Science, Kasetsart University. This research was approved by the Institutional Animal Care and Use Committee of Faculty of Science, Kasetsart University (project number ACKU60-SCI-004). Wachara Sanguansombat and Sunchai Makchai (Thailand Natural History Museum) made specimens in their care available for study. Attapol Rujirawan, Korkhwan Termprayoon, Siriporn Yodthong and Piyawan Puenprapai assisted with fieldwork. Evan S. H. Quah and Vinh Q. Luu improved the manuscript. This paper is contribution number 917 of the Auburn University Museum of Natural History.

\section{References}

Ampai N, Rujirawan A, Wood PL Jr, Stuart BL, Aowphol A (2019) Morphological and molecular analyses reveal two new species of Cnemaspis Strauch, 1887 (Squamata, Gekkonidae) from Satun Province, southern Thailand. ZooKeys 858: 127-161. https://doi. org/10.3897/zookeys.858.34297

Bauer AM, Das I (1998) A new Cnemaspis (Reptilia: Gekkonidae) from Southeastern Thailand. Copeia 1998(2): 439-444. https://doi.org/10.2307/1447438

Bauer AM, De Silva A, Greenbaum E, Jackman T (2007) A new species of day gecko from high elevation in Sri Lanka, with a preliminary phylogeny of Sri Lankan Cnemaspis (Reptilia: Squamata: Gekkonidae). Mitteilungen aus dem Museum für Naturkunde, Berlin, Zoologische Reihe 83: 22-32. https://doi.org/10.1002/mmnz.200600022

Bauer AM, Giri VB, Greenbaum E, Jackman T, Dharne MS, Shouche SY (2008) On the Systematics of the Gekkonid Genus Teratolepis Günther, 1869: Another One Bites the Dust. Hamadryad 32(2): 90-104. 
Charusiri, P, Clark AH, Farrar E, Archibald D, Charusiri B (1993) Granite belts in Thailand: Evidence from the ${ }^{40} \mathrm{Ar} /{ }^{39} \mathrm{Ar}$ geochronological and geological synthesis. Journal of Southeast Asian Earth Sciences 8: 127-136. https://doi.org/10.1016/0743-9547(93)90014-G

Cobbing EJ (2011) Granitic rocks. In: Ridd MF, Barber AJ, Crow MJ (Eds) The Geology of Thailand. The Geological Society, London, 537-550. https://doi.org/10.1144/GOTH.16

Das I (2005) Revision of the genus Cnemaspis Strauch, 1887 (Sauria: Gekkonidae), from the Mentawai and Adjacent Archipelagos of Western Sumatra, Indonesia, with description of four new species. Journal of Herpetology 39(2): 233-247. https://doi.org/10.1670/61-02A

Das I, Leong TM (2004) A new species of Cnemaspis (Sauria: Gekkonidae) from Southern Thailand. Current Herpetology 23(2): 63-71. https://doi.org/10.5358/hsj.23.63

Dayrat B (2005) Towards integrative taxonomy. Biological Journal of the Linnean Society 85: 407-415. https://doi.org/10.1111/j.1095-8312.2005.00503.x

Gamble T, Greenbaum E, Jackman TR, Russell AP, Bauer AM (2012) Repeated origin and loss of adhesive toepads in geckos. PLoS ONE 7: e39429. https://doi.org/10.1371/journal. pone.0039429

Grismer LL, Chan KO (2010) Another new Rock Gecko (genus Cnemaspis Stauch 1887) from Pulau Langkawi, Kedah, Peninsular Malaysia. Zootaxa 2419: 51-62. https://doi. org/10.11646/zootaxa.2419.1.2

Grismer LL, Chan KO, Nurolhuda N, Sumontha M (2008a) A new species of karst dwelling gecko (genus Cnemaspis Strauch 1887) from the border region of Thailand and Peninsular Malaysia. Zootaxa 1875: 51-68. https://doi.org/10.11646/zootaxa.1875.1.4

Grismer LL, Grismer JL, Wood PL Jr, Chan KO (2008b) The distribution, taxonomy, and redescription of the geckos Cnemaspis affinis (Stoliczka 1887) and C. flavolineata (Nicholls 1949) with descriptions of a new montane species and two new lowland, karst-dwelling species from Peninsular Malaysia. Zootaxa 1931: 1-24. https://doi.org/10.11646/ zootaxa.1931.1.1

Grismer LL, Ngo VT (2007) Four new species of the gekkonid genus Cnemaspis Strauch 1887 (Reptilia: Squamata) from Southern Vietnam. Herpetologica 63(4): 482-500. https://doi. org/10.1655/0018-0831(2007)63[482:FNSOTG]2.0.CO;2

Grismer LL, Norhayati A, Chan KO, Daicus B, Muin MA, Wood PL Jr, Grismer JL (2009) Two new diminutive species of Cnemaspis Strauch 1887 (Squamata: Gekkonidae) from Peninsular Malaysia. Zootaxa 2019: 40-56. https://doi.org/10.11646/zootaxa.2019.1.3

Grismer LL, Sumontha M, Cota M, Grismer JL, Wood PL Jr, Pauwels OS, Kunya K (2010) A revision and redescription of the rock gecko Cnemaspis siamensis (Taylor 1925) (Squamata: Gekkonidae) from Peninsular Thailand with descriptions of seven new species. Zootaxa 2576: 1-55. https://doi.org/10.11646/zootaxa.2576.1.1

Grismer LL, Wood PL Jr, Tri N, Murdoch ML (2015a) The systematics and independent evolution of cave ecomorphology in distantly related clades of Bent-toed Geckos (Genus Cyrtodactylus Gray, 1827) from the Mekong Delta and islands in the Gulf of Thailand. Zootaxa 3980(1): 106-126. https://doi.org/10.11646/zootaxa.3980.1.6

Grismer LL, Wood PL Jr, Mohamed M, Chan KO, Heinz HM, Sumaril ASI, Chan JA, Loredo AI (2013) A new species of karst-adapted Cnemaspis Strauch, 1887 (Squamata: Gekkonidae from a threatened karst region in Pahang, Peninsular Malaysia. Zootaxa 3746(3): 463-472. https://doi.org/10.11646/zootaxa.3746.3.5 
Grismer LL, Wood PL Jr, Quah ES, Anuar S, Ngadi E, Norhayati A (2015b) A new insular species of Rock Gecko (Cnemaspis Boulenger) from Pulau Langkawi, Kedah, Peninsular Malaysia. Zootaxa 3985(2): 203-218. https://doi.org/10.11646/zootaxa.3985.2.2

Grismer LL, Wood PL Jr, Shahrul A, Awal R, Norhayati A, Muin M, Sumontha M, Grismer J, Chan K, Quah ES, Pauwels O (2014) Systematics and natural history of Southeast Asian Rock Geckos (genus Cnemaspis Strauch, 1887) with descriptions of eight new species from Malaysia, Thailand, and Indonesia. Zootaxa 3880(1): 1-147. https://doi.org/10.11646/ zootaxa.3880.1.1

Hammer Ø, Harper DAT, Ryan PD (2001) PAST: Paleontological Statistics Software Package for Education and Data Analysis. Palaeontologia Electronica 4: 1-9.

Huelsenbeck JP, Ronquist F (2001) MRBAYES: Bayesian inference of phylogeny. Bioinformatics 17: 754-755. https://doi.org/10.1093/bioinformatics/17.8.754

Jombart T (2008) Adegenet: A R package for the multivariate analysis of genetic markers. Bioinformatics 24: 1403-1405. https://doi.org/10.1093/bioinformatics/btn129

Jombart T, Devillard S, Balloux F (2010) Discriminant analysis of principal components: a new method for the analysis of genetically structured populations. BMC Genetics 11: 1-94. https://doi.org/10.1186/1471-2156-11-94

Kaiser HF (1960) The Application of Electronic Computers to Factor Analysis. Educational and Psychological Measurement 20: 141-151. https://doi.org/10.1177/001316446002000116 Kalyaanamoorthy S, Minh BQ, Wong TK, von Haeseler A, Jermiin LS (2017) ModelFinder: fast model selection for accurate phylogenetic estimates. Nature Methods 14: 587-589. https://doi.org/10.1038/nmeth.4285

Kumar SSG, Stecher G, Tamura K (2016) MEGA7: molecular evolutionary genetics analysis version 7.0 for bigger data sets. Molecular Biology and Evolution 33(7): 1870-1874. https://doi.org/10.1093/molbev/msw054

Kurita T, Nishikawa K, Matsui M, Hikida T (2017) A new species of Rock Gecko genus Cnemaspis (Squamata: Gekkonidae) from Western Sarawak, Malaysia. Zootaxa 4258(5): 525538. https://doi.org/10.11646/zootaxa.4258.5.2

Lleonart J, Salat J, Torres GJ (2000) Removing allometric effects of body size in morphological analysis. Journal of Theoretical Biology 205: 85-93. https://doi.org/10.1006/jtbi.2000.2043

Macey JR, Larson A, Ananjeva NB, Papenfuss TJ (1997) Evolutionary shifts in three major structural features of the mitochondrial genome among iguanian lizards. Journal of Molecular Evolution 44: 660-674. https://doi.org/10.1007/PL00006190

Miller MA, Pfeiffer W, Schwartz T (2010) Creating the CIPRES Science Gateway for Inference of Large Phylogenetic Trees in Proceedings of the Gateway Computing Environments Workshop (GCE), 14 Nov. 2010, New Orleans, 8 pp. https://doi.org/10.1109/ GCE.2010.5676129 [assessed 17 August 2019]

Minh Q, Nguyen M, von Haeseler AA (2013) Ultrafast approximation for phylogenetic bootstrap. Molecular Biology and Evolution 30: 1188-1195. https://doi.org/10.1093/molbev/mst024

Nguyen LT, Schmidt HA, von Haeseler A, Minh BQ (2015) IQ-TREE: a fast and effective stochastic algorithm for estimating maximum-likelihood phylogenies. Molecular Biology and Evolution 32: 268-274. https://doi.org/10.1093/molbev/msu300

Posada D (2008) jModelTest: Phylogenetic model averaging. Molecular Biology and Evolution 25(7): 1253-1256. https://doi.org/10.1093/molbev/msn083 
Pyron RA, Burbrink FT, Wiens JJ (2013) A phylogeny and revised classification of Squamata, including 4161 species of lizards and snakes. BMC Evolutionary Biology 13: 1-53. https:// doi.org/10.1186/1471-2148-13-93

R Core Team (2018) R: A Language and Environment for Statistical Computing. R Foundation for Statistical Computing, Vienna. https://www.R-project.org

RStudio Team (2018) RStudio: Integrated Development for R. RStudio, Inc., Boston. http:// www.rstudio.com/

Rambaut A (2009) FigTree version 1.4.3. http://tree.bio.ed.ac.uk/software/figtree

Rambaut A, Suchard MA, Xie D, Drummond AJ (2014) Tracer v1.6. http://beast.bio.ed.ac.uk/ Tracer [assessed 25 August 2018]

Riyanto A, Hamidy A, Sidik I, Gunalen D (2017) A new species of Rock Gecko of the genus Cnemaspis Strauch, 1887 (Squamata: Gekkonidae) from Belitung Island, Indonesia. Zootaxa 4358: 583-597. https://doi.org/10.11646/zootaxa.4358.3.12

Smith MA (1925) Contribution to the herpetology of Borneo. The Sarawak Museum Journal 3(8): 15-34.

Strauch AA (1887) Bemerkungen über die Geckoniden-Sammlung im zoologischen Museum der kaiserlichen Akademie der Wissenschaften zu St. Petersburg. Mémoires des Savants Étrangers 7: 1-72.

Taylor EH (1963) The lizards of Thailand. The University of Kansas science bulletin 44: 687-1077.

Trifinopoulos J, Nguyen LT, von Haeseler A, Minh BQ (2016) W-IQ-TREE: a fast online phylogenetic tool for maximum likelihood analysis. Nucleic Acids Research 44(W1): W232W235. https://doi.org/10.1093/nar/gkw256

Thorpe RS (1975) Quantitative handling of characters useful in snake systematics with particular reference to interspecific variation in the Ringed Snake Natrix natrix (L.). Biological Journal of the Linnean Society 7: 27-43. https://doi.org/10.1111/j.1095-8312.1975.tb00732.x

Thorpe RS (1983) A review of the numerical methods for recognized and analysing racial differentiation. In: Felsenstein J (Ed.) Numerical Taxonomy. Berlin Heidelberg: Springer, 404-423. https://doi.org/10.1007/978-3-642-69024-2_43

Turan, C (1999) A note on the examination of morphome-tric differentiation among fish populations: the truss system. Turkish Journal of Zoology 23: 259-263.

Uetz P, Freed P, Hošek J (2019) The Reptile Database. http://www.reptile-database.org [accessed 29 August 2019]

Wickham H (2016) ggplot2: Elegant Graphics for Data Analysis. Springer-Verlag, New York, 216 pp. https://doi.org/10.1007/978-3-319-24277-4_9

Wilcox TP, Zwickl DJ, Heath TA, Hillis DM (2002) Phylogenetic relationships of the dwarf boas and a comparison of Bayesian and bootstrap measures of phylogenetic support. Molecular Phylogenetics and Evolution 25: 361-371. https://doi.org/10.1016/S10557903(02)00244-0

Wood PL Jr, Grismer LL, Aowphol A, Aguilar CA, Cota M, Grismer MS, Murdoch ML, Sites Jr JW (2017) Three new karst-dwelling Cnemaspis Strauch, 1887 (Squamata; Gekkonidae) from Peninsular Thailand and the phylogenetic placement of $C$. punctatonuchalis and $C$. vandeventeri. PeerJ 5: e2884. https://doi.org/10.7717/peerj.2884 
Wood PL Jr, Quah ES, Anuar S, Muin MA (2013) A new species of lowland karst dwelling Cnemaspis Strauch 1887 (Squamata: Gekkonidae) from northwestern Peninsular Malaysia. Zootaxa 3691(5): 538-558. https://doi.org/10.11646/zootaxa.3691.5.2

\section{Appendix I}

List of comparative specimens examined.

Cnemaspis adangrawi: Thailand, Satun Province, Mueang Satun District, Adang Island: ZMKU R 00767 (male holotype), ZMKU R 00769-70, THNHM 28206-09 (6 males), ZMKU R 00768, ZMKU R 00771 (2 females); Thailand, Satun Province, Mueang Satun District, Rawi Island: ZMKU R 00773, ZMKU R 00775 , THNHM 28210 (3 adult males), ZMKU R 00774, THNHM 28211 (2 females).

Cnemaspis chanardi: Thailand, Trang Province, Nayong District, Ban Chong: THNHM 06983 (male holotype); Krabi Province, Klong Thom District: THNHM 012439-40 (males); Mueang Krabi District: THNHM 012436-37 (males), THNHM 012438 (female); Nakhon Si Thammarat Province, Tha Sala District: THNHM 020992 (male); Lansaka district: THNHM 014111 (immature male); Noppitam district: THNHM 013838 (male), THNHM 010705 (male); Surat Thani Province, Ang Thong Island, Mueang Surat Thani District: THNHM 016074 (female).

Cnemaspis huaseesom: Thailand, Kanchanaburi Province, Sai Yok District, Sai Yok National Park: THNHM 15909 (male holotype).

Cnemaspis niyomwanae: Thailand, Trang Province, Palean District, Thum Khao Ting: THNHM 15909 (female holotype).

Cnemaspis punctatonuchalis: Thailand, Prachuap Khiri Khan Province, Thap Sakae District, Huay Yang National Park: THNHM 02001 (male holotype)

Cnemaspis siamensis: Thailand, Nakhon Si Thammarat Province, Lan saka District: THNHM 013828 (male); Tha Sala District: THNHM 018265 (male); Phetchabun Province, Nam Nao District: THNHM 01336 (female), THNHM 01337 (male); Phetchaburi Province, Cha-am District: THNHM 01448 (male), THNHM 01449 (immature male); Chumpon Province, Mueang Chumpon District: THNHM 0372 (male); Phato District: THNHM 01086 (male); Surat Thani Province, Vibhawadee District: THNHM 01084 (female); Ang Thong Island, Mueang Surat Thani District: THNHM 015624 (female).

Cnemaspis vandeventeri: Thailand, Ranong Province, Kapur District, Klong Naka: THNHM 08261 (male holotype), THNHM 08260 (female). 